\title{
Analysis of the Production Cost for Various Grades of Biomass Thermal Treatment
}

Robert S. Cherry

Rick A. Wood

Tyler L. Westover

December 2013

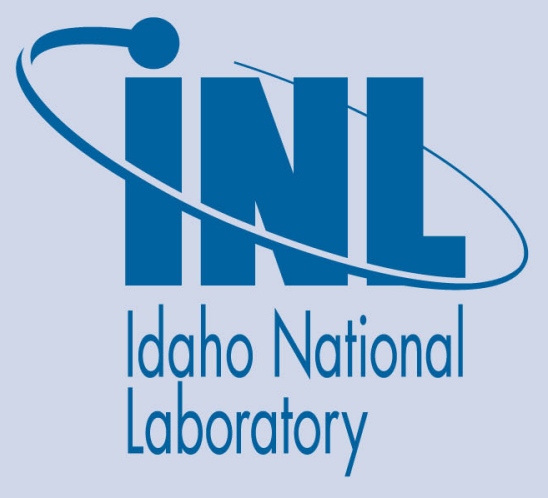

The INL is a U.S. Department of Energy National Laboratory operated by Battelle Energy Alliance 


\section{DISCLAIMER}

This information was prepared as an account of work sponsored by an agency of the U.S. Government. Neither the U.S. Government nor any agency thereof, nor any of their employees, makes any warranty, expressed or implied, or assumes any legal liability or responsibility for the accuracy, completeness, or usefulness, of any information, apparatus, product, or process disclosed, or represents that its use would not infringe privately owned rights. References herein to any specific commercial product, process, or service by trade name, trade mark, manufacturer, or otherwise, does not necessarily constitute or imply its endorsement, recommendation, or favoring by the U.S. Government or any agency thereof. The views and opinions of authors expressed herein do not necessarily state or reflect those of the U.S. Government or any agency thereof. 
INL/EXT-13-30348

Rev. 1

\title{
Analysis of the Production Cost for Various Grades of Biomass Thermal Treatment
}

\author{
Robert S. Cherry \\ Rick A. Wood ${ }^{1}$ \\ Tyler L. Westover \\ ${ }^{1}$ British Petroleum
}

December 2013

Idaho National Laboratory

Idaho Falls, Idaho 83415

http://www.inl.gov

Prepared for the

U.S. Department of Energy

Assistant Secretary for Energy Efficiency and Renewable Energy

Under DOE Idaho Operations Office

Contract DE-AC07-05ID14517 



\begin{abstract}
Process flow sheets were developed for the thermal treatment of southern pine wood chips at four temperatures $\left(150,180,230\right.$, and $\left.270{ }^{\circ} \mathrm{C}\right)$ and two different scales (20 and 100 ton/hour). The larger capacity processes had as their primary heat source hot gas assumed to be available in quantity from an adjacent biorefinery. Mass and energy balances for these flow sheets were developed using Aspen Plus process simulation software. The hot gas demands in the larger processes, up to 1.9 million $\mathrm{lb} /$ hour, were of questionable feasibility because of the volume to be moved. This heat was of low utility because the torrefaction process, especially at higher temperatures, is a net heat producer if the organic byproduct gases are burned. A thermal treatment flow sheet using wood chips dried in the biorefinery to $10 \%$ moisture content (rather than $30 \%$ for green chips) with transfer of high temperature steam from the thermal treatment depot to the biorefinery was also examined. The equipment size information from all of these cases was used in several different equipment cost estimating methods to estimate the major equipment costs for each process. From these, factored estimates of other plant costs were determined, leading to estimates $( \pm 30 \%$ accuracy) of total plant capital cost. The 20 ton/hour processes were close to 25 million dollars except for the $230^{\circ} \mathrm{C}$ case using dried wood chips which was only15 million dollars because of its small furnace. The larger processes ranged from 64-120 million dollars. From these capital costs and projections of several categories of operating costs, the processing cost of thermally treated pine chips was found to be $\$ 28-33$ per ton depending on the degree of treatment and without any credits for steam generation. If the excess energy output of the two $20 \mathrm{ton} / \mathrm{hr}$ depot cases at $270{ }^{\circ} \mathrm{C}$ can be sold for $\$ 10$ per million BTU, the net processing cost dropped to $\$ 13 /$ ton product starting with green wood chips or only $\$ 3$ per ton if using dried chips from the biorefinery. Including a $12 \%$ return on invested capital raised all of the operating cost results by about $\$ 20 /$ ton.
\end{abstract}




\section{CONTENTS}

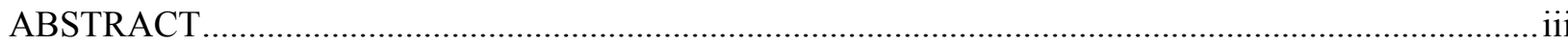

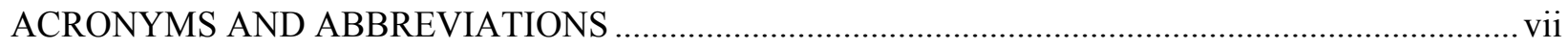

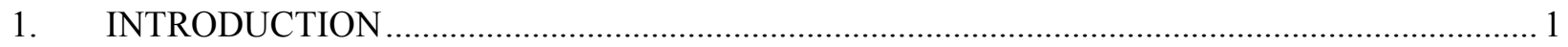

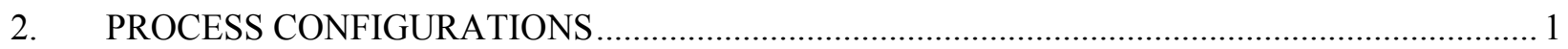

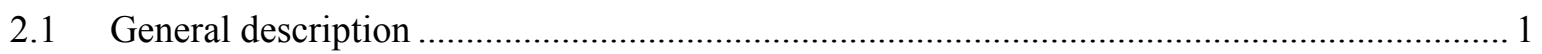



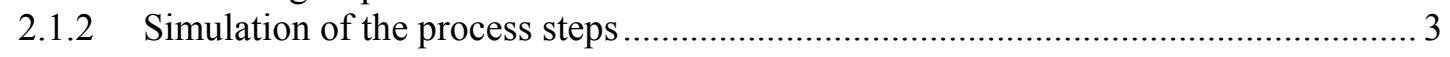



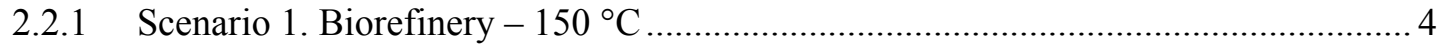

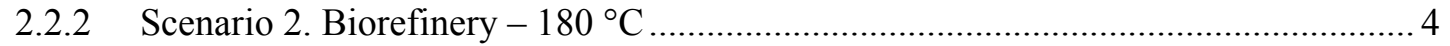

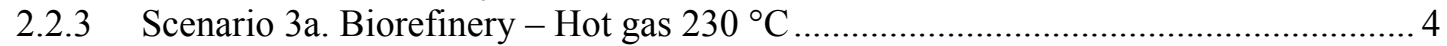

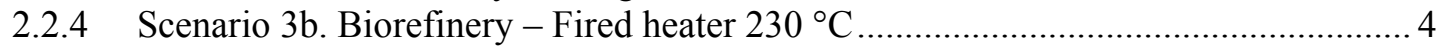

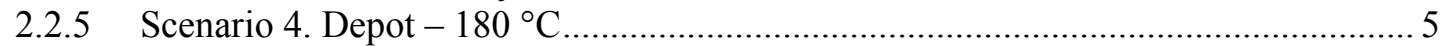

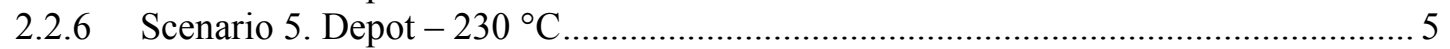

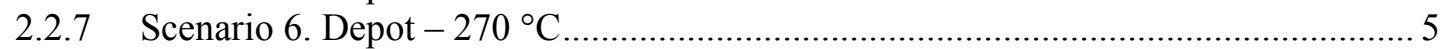

2.2.8 Scenario 7. Depot $-230^{\circ} \mathrm{C}-$ Integrated with biorefinery .................................... 5

2.2.9 Scenario 8. Depot $-270^{\circ} \mathrm{C}-$ Integrated with biorefinery ....................................... 5

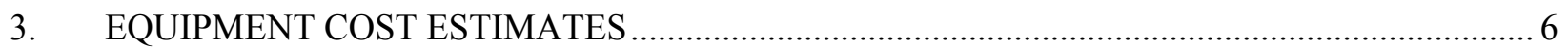

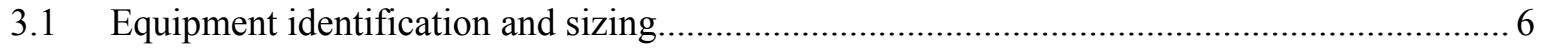

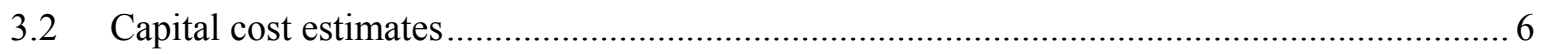

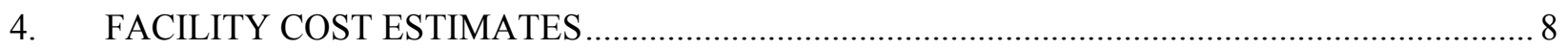



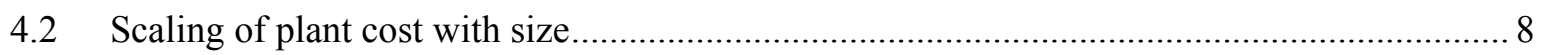

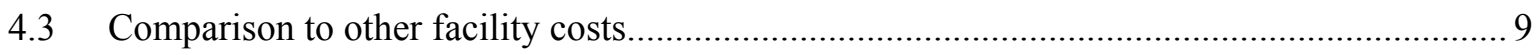

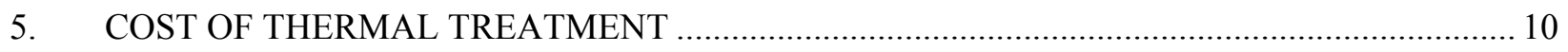

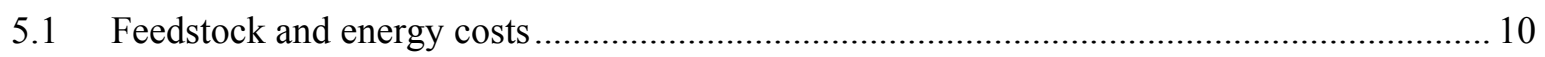



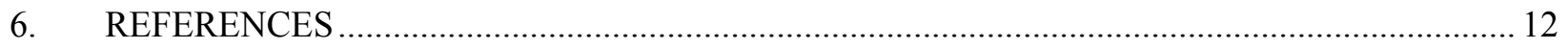

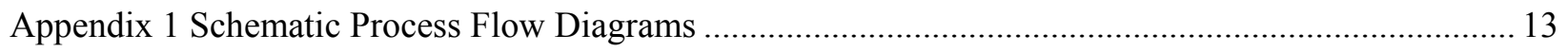

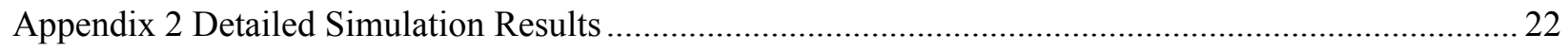

Appendix 3 Individual Equipment Item Cost Estimates.................................................................. 32

Appendix 4 Derivation of Equipment Cost Estimates .................................................................. 35

Appendix 5 Example Factored Estimate of Total Facility Cost ...................................................... 40 


\section{TABLES}

Table 1. Wood product yield at various processing temperatures ............................................................2

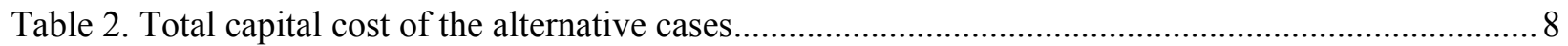



Table 4. Energy feeds to depot-scale processes making 20 ton per hour of product ................................ 10

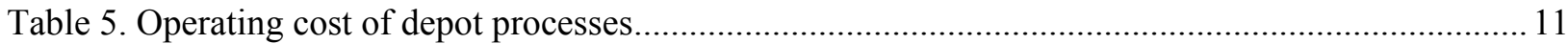

\section{FIGURES}

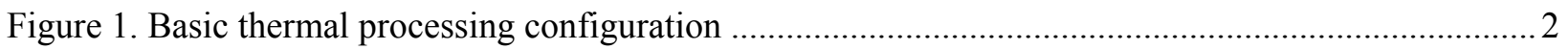

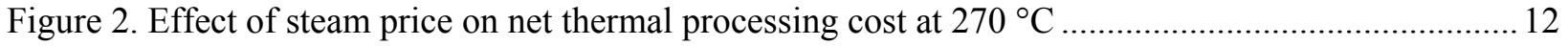




\section{ACRONYMS AND ABBREVIATIONS}

$\begin{array}{ll}\text { BTU } & \text { British thermal unit } \\ \text { C } & \text { Celsius } \\ \text { HHV } & \text { higher heating value } \\ \text { HP } & \text { horsepower } \\ \text { INL } & \text { Idaho National Laboratory } \\ \text { kW } & \text { kilowatt } \\ \text { kWh } & \text { kilowatt-hour } \\ \text { M } & \text { million } \\ \text { MW } & \text { megawatt }\end{array}$




\section{Analysis of the Production Cost for Various Grades of Biomass Thermal Treatment}

\section{INTRODUCTION}

Freshly harvested biomass has high moisture content (up to $50 \mathrm{wt} \%$ ), low energy content per unit mass, and low volumetric density. Neither is it aerobically stable, losing some of its energy content through microbial metabolism while in storage. These characteristics reduce its attractiveness as a feedstock for fuels or chemicals. However, by thermal treatment at $180-300{ }^{\circ} \mathrm{C}$ in the absence of oxygen to prevent combustion, it can be dried, densified, stabilized, and made more frangible and susceptible to further size reduction. Treatment at $180-220^{\circ} \mathrm{C}$ is known as semi-reactive drying while treatment at 220 $300{ }^{\circ} \mathrm{C}$ is commonly referred to as torrefaction.

Thermal treatment of biomass generates solids and a gas-phase product composed primarily of steam from evaporated moisture and thermally disrupted hydroxyl $(-\mathrm{OH})$ groups. The hot gas also contains noncondensable $\mathrm{CO}_{2}$ and some $\mathrm{CO}$ as well as condensable organic molecules such as methanol, acetic acid, and formaldehyde, all coming from the biomass. The high oxygen content of these by-products leads to a lower oxygen content, and therefore higher carbon content and fuel value, in the treated biomass. Depending on the type of biomass, its initial moisture content, and the temperature and duration of its treatment, $20-50 \%$ of the feed biomass weight can be lost to the gas phase as water and small organics.

In a commercial scale process, this gas cannot be discharged to the atmosphere. Not only would the organic content pose problems with odor and atmospheric emissions, the potential fuel value of those molecules would be lost. By burning or oxidizing the organic molecules in that stream, heat can be generated for use in the thermal treatment process. However, doing this requires additional equipment including a burner of some kind and heat exchangers.

This report examines heat-integrated thermal treatment processes designed for different temperatures and scale of operation. To simplify this analysis, all use southern pine wood chips as the feed. The objective is to develop estimates of the capital and operating costs for such plants and to determine the cost of thermal treatment per unit of biomass processed. Knowing this cost, system designers can assess the desirability of thermally treating biomass to improve its handling, storage, and processing properties.

\section{PROCESS CONFIGURATIONS}

\subsection{General description}

\subsubsection{Processing steps}

The general structure of the various process flow sheets is similar, with the primary differences being in their heat integration. One major variable is the assumed production rate of torrefied wood. Four cases assume 100 ton/hour production rate and a location near a large biomass refinery that produces excess heat usable for drying and torrefaction. That heat is assumed to be available as $282{ }^{\circ} \mathrm{C}$ purge gas from the biorefinery. After its heat is used in the thermal treatment process the gas is vented to the atmosphere. Another three assume 20 ton/hour production, representative of a regional depot for biomass collection and about equal to $25 \%$ of the maximum biomass available within an economical transport radius. An eighth case uses a 20 ton/hour depot adjacent to a biorefinery that supplies dried wood chips to the depot and that can productively use a substantial heat flow from burning of the torrefier off-gas. 
The other major variable in this study is the temperature of the torrefaction step, with values of 150 , 180,230 , and $270{ }^{\circ} \mathrm{C}$. The lowest value essentially only dries the wood chips from their assumed initial moisture content of $30 \%$ to $10 \%$, while higher temperatures cause increasing thermal decomposition of the wood with release of greater amounts of volatile organic species (Table 1). With the more severe processing, the solid product has higher energy density and heating value, but less of it is produced from each unit of feed wood. However, this also means that more heat can be generated within the process by oxidizing the offgas.

\section{Table 1. Wood product yield at various processing temperatures}

\begin{tabular}{|c|c|}
\hline $\begin{array}{c}\text { Processing } \\
\text { temperature }\left({ }^{\circ} \mathrm{C}\right)\end{array}$ & $\begin{array}{c}\text { Solid product yield } \\
\text { (\% dry feed) }\end{array}$ \\
\hline 150 & 99 \\
\hline 180 & 97 \\
\hline 230 & 95 \\
\hline 270 & 84 \\
\hline
\end{tabular}

The basic process configuration for processing at $230{ }^{\circ} \mathrm{C}$ (Westover et al. 2013, Phanphanich and Mani 2011) is illustrated in Figure 1. The specific variations of this configuration will be discussed separately for each alternative set of conditions. The main wood feed is at the top center, where chipped wood is fed from a hopper into a rotary drum dryer. The heat source for this direct contact dryer is hot flue gas from a stoker furnace that burns a separate feed stream of the same wood chips. Hot dry wood chips from the dryer and moisture-containing flue gas move to a combined surge bin and cyclone that act as a gas-solids separator. Any fine solids in the gas stream are captured in a baghouse; this is expected to be a negligible fraction of the wood fed to the system.

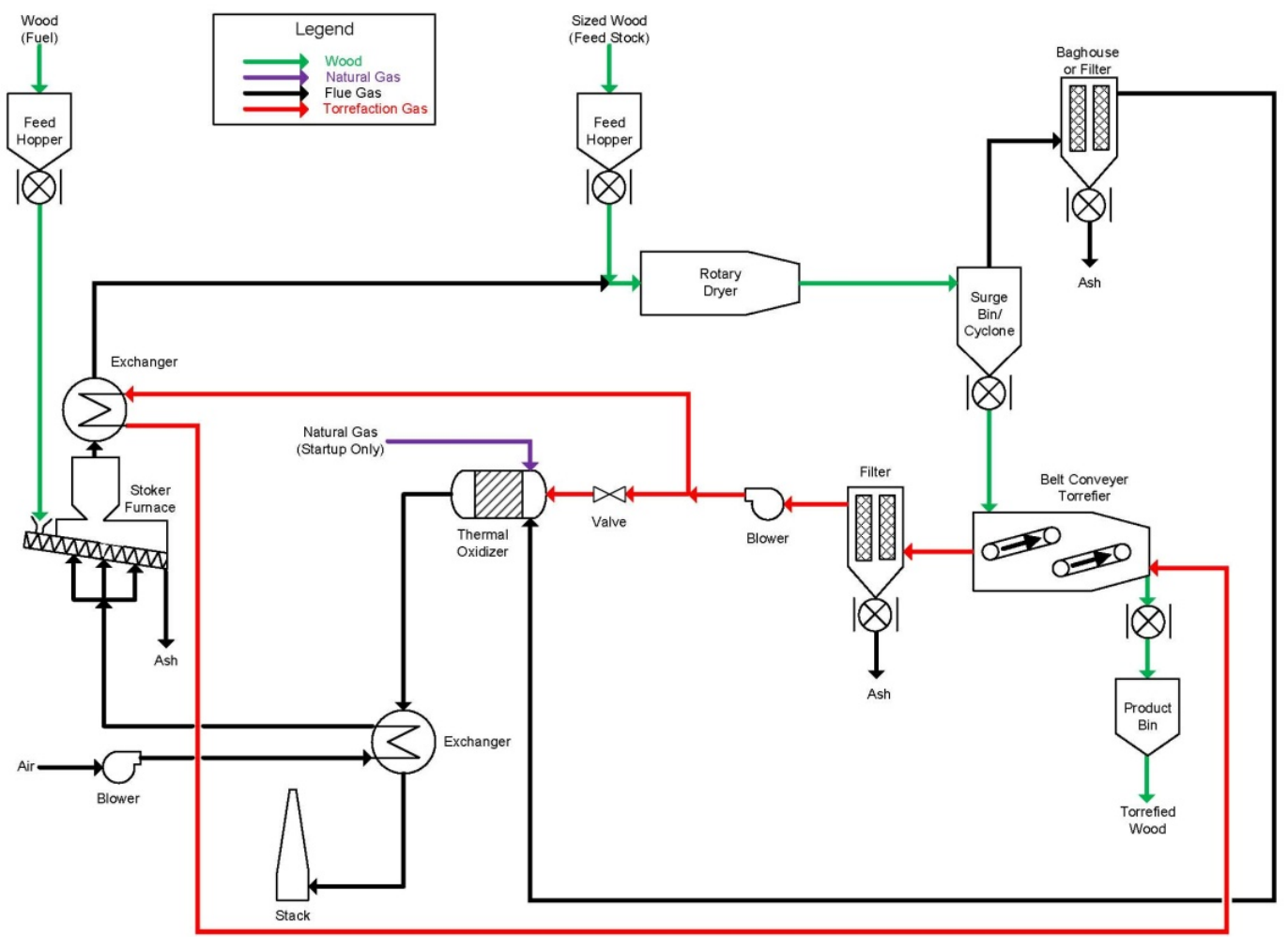

Figure 1. Basic thermal processing configuration 
The dried wood chips are fed from the surge bin to the torrefier. This item is assumed to be similar to a conveyor type dryer but with a higher operating temperature and a design that prevents air infiltration. The torrefied chips leaving this process step are transported to a large product bin. The torrefier off-gas, primarily water vapor, carbon dioxide, and small organic molecules, is filtered to remove any dust resulting from solids handling in the torrefier. A blower moves the offgas through a heat exchanger on the stoker furnace flue gas stream. This reheated gas flows back to the torrefier to provide the thermal energy for this endothermic reaction.

The hot gas exiting the torrefier contains vaporized organic molecules that must be purged to maintain the material balance. Downstream of the blower, part of the offgas is diverted to a regenerative thermal oxidizer where the organics are combusted. A small stream of natural gas is fed to the oxidizer for startup and to ensure reliable combustion. The oxygen for this combustion comes from the gas stream leaving the surge bin after the wood chip dryer. This stream contains excess oxygen from the stoker furnace as well as a large amount of evaporated moisture that reduces oxidizer performance. The outlet stream of the thermal oxidizer is gas at roughly $300{ }^{\circ} \mathrm{C}$ that is used to preheat the air to the stoker furnace, improving the efficiency of that operation. That still-hot thermal oxidizer effluent stream is then vented to the atmosphere through an exhaust stack. Although it appears that heat is wasted by venting hot gas, a temperature well above the dew point is needed to prevent water condensation and corrosion in the exhaust stack and to assure that the discharged plume rises and disperses in the open atmosphere.

\subsubsection{Simulation of the process steps}

Mass and energy balances for the various alternative flow sheets were prepared using Aspen Plus software, version 7.3. The desired flow rate of the product torrefied wood was specified as were the compositions of the several feed streams: raw wood chips, air, natural gas, and for some cases the hot gas from the biorefinery.

In general, the simulated unit operations (process steps) matched those on the schematic flow diagrams with two main exceptions. In the first, because Aspen Plus is a thermodynamically based simulator, the mechanical aspects of the equipment items were not incorporated in the model. For instance, the stoker furnace is modeled as combustion of the feed streams, but the physical arrangement of the equipment is not part of the simulation. The same is true of heat exchangers, air preheaters, the wood chip dryer and torrefier, and the regenerative thermal oxidizer. The significance of this is that there is flexibility and judgment required in preparing capital cost estimates from the results of the process simulations.

The second difference, somewhat related to the first, is in how the torrefaction and, for cases with one, the stoker furnace were represented in the models. The indeterminate chemical makeup of wood and the complex chemistry of torrefaction prevent simulation of defined reactions of specified compounds, the usual approach in Aspen. Instead, the torrefier reactions (and, using analogous steps, the furnace reactions) were modeled as a two step sequence of breaking down the wood feed streams to the elementary components $\mathrm{H}_{2} \mathrm{O}, \mathrm{H}_{2}, \mathrm{O}_{2}, \mathrm{C}$, and torrefied wood of composition specified by its ultimate analysis. In a second step the gaseous materials were recombined to form water and acetic acid $\left(\mathrm{CH}_{3} \mathrm{COOH}\right)$, a major product of actual torrefaction that was used to stand for all the various organic molecules produced in the reaction. With this separation of reaction steps, Aspen could predict the enthalpy changes in each step and by summing them obtain the correct overall enthalpy change for the energy balance. However, this approach puts two "torrefier" units on the flow sheet with streams of physically unrealistic composition flowing from one to the other. Their combined enthalpy change was used to specify how much heat was transferred in another artificially separate step from the recirculating hot gas into the torrefaction products. Although complicated, this approach allows the Aspen simulations to ensure a proper mass balance while calculating the energy balance for the whole process. 


\subsection{Specific alternative cases}

The following subsections describe the eight cases modeled with emphasis on how they differ from each other. The schematic diagrams providing an overview of each process configuration are collected in Appendix 1. The detailed flow sheets showing the Aspen simulation flow sheet as well as all heat flows and stream temperatures, pressures, and flow rates are collected in Appendix 2. Those results are reported in English units of MBTU (thousands of British Thermal Units) per hour, degrees Fahrenheit, pounds force per square inch absolute, and pounds mass per hour.

\subsubsection{Scenario 1. Biorefinery $-150^{\circ} \mathrm{C}$}

This case corresponds to a large production (100 ton/hour) of wood chips that are deep dried with relatively little thermal transformation. Nonetheless, there are enough volatile organic byproducts in the dryer offgas that to avoid odor complaints the stream is treated in a thermal oxidizer. Heat for drying the wood chips comes entirely from once-through use of a hot gas stream (composed of $\mathrm{N}_{2}, \mathrm{H}_{2} \mathrm{O}, \mathrm{CO}_{2}$, and a small amount of $\mathrm{O}_{2}$ ) obtained from an adjacent biorefinery described in Dutta et al. 2011. This biorefinery generates about $879,000 \mathrm{lb} / \mathrm{hr}$ of this gas at $262{ }^{\circ} \mathrm{C}$, whereas the thermal treatment system requires about $1,240,000 \mathrm{lb} / \mathrm{hr}$ of this gas to produce $100 \mathrm{ton} /$ hour of thermally treated wood. Because these two plants were designed independent of each other, there is opportunity to correct this mismatch by adjusting the size of the torrefaction unit or the amount and temperature of the biorefinery hot gas. But the practicality of even the smaller value here is debatable: using a rule of thumb for sizing lines carrying gases (design them for $100 \mathrm{ft} / \mathrm{sec}$ velocity), the delivery pipe or duct would be ten feet in diameter or about the diameter expected for a large exhaust stack. Heat exchangers and other equipment carrying this gas would require comparably large flow channels.

\subsubsection{Scenario 2. Biorefinery $-180^{\circ} \mathrm{C}$}

In contrast to the trend at higher temperatures, going from 150 to $180{ }^{\circ} \mathrm{C}$ leads to an increase in the amount of heat that must obtained externally. This is because of the increased amount of endothermic torrefaction that occurs at the higher temperature as well as an increased demand for oxygen in the oxidizer. The hot gas is now split between the drying step (similar to the previous case) and a new use in the torrefier. The amount of oxygen $(2.7 \%)$ in the biorefinery gas is not sufficient to oxidize all the organics generated in torrefaction, so a new air feed is needed in the thermal oxidizer. Not only is this air feed cold, but it is $80 \%$ inert nitrogen and argon that have no process benefit but do contribute to the thermal demand. The consequences are seen in the increased flow of natural gas to the thermal oxidizer and in the increased demand for hot gas from the biorefinery, now up to $1,550,000 \mathrm{lb} / \mathrm{hr}$.

\subsubsection{Scenario 3a. Biorefinery - Hot gas $230^{\circ} \mathrm{C}$}

This case continues the trend of the previous two using biorefinery hot gas. A new constraint on operation is evident: running the torrefaction unit at $230{ }^{\circ} \mathrm{C}$ using heat available at $282{ }^{\circ} \mathrm{C}$ requires more gas flow because no more than $52^{\circ} \mathrm{C}$ of sensible heat is recoverable, in contrast to the $102^{\circ} \mathrm{C}$ available to thermal treatment running at $180^{\circ} \mathrm{C}$. In a practical system, the amount of heat recovered will be less than this. An advantage of this higher hot gas flow is that it carries enough total oxygen that supplemental air (with its unwanted thermal load) is not needed in the thermal oxidizer. The projected biorefinery gas flow for this case is 1,940,000 $\mathrm{lb} / \mathrm{hr}$ and requires a delivery pipe over 14 feet in diameter.

\subsubsection{Scenario 3 b. Biorefinery - Fired heater $230^{\circ} \mathrm{C}$}

This case is an alternative process configuration to obtain the same torrefaction conditions and product rate as the previous case. As with all the biorefinery-scale cases, once-through biorefinery hot gas is used to dry the incoming wood pellets. In this alternative, to address the limited amount of sensible heat recoverable from the hot gas a fired heater provides the enthalpy needed in the torrefaction step. It burns the torrefaction offgas and some supplemental natural gas. The high furnace outlet temperature allows a much smaller (30\% as large) recirculating gas flow than in the once-through biorefinery gas case to carry 
enthalpy into the torrefier. The furnace effluent carries sufficient enthalpy that it can also be used to preheat the combustion air, reducing the required amount of natural gas and combustion air. Even with these changes to reduce hot gas usage, the flow sheet still calls for $1,020,000 \mathrm{lb} / \mathrm{hr}$ from the biorefinery.

\subsubsection{Scenario 4. Depot $-180^{\circ} \mathrm{C}$}

This 20 ton/hour process alternative uses a relatively low temperature in the thermal treatment step and therefore produces a small amount of organic offgas there. Because of the low heating value of the gas purged from that loop, a supplemental feed of natural gas to the regenerative thermal oxidizer is necessary to assure a stable combustion there. In addition, some additional wood chips must be fed to a stoker furnace to provide the total amount of heat needed in the process. Low grade or waste biomass such as forest trimmings and slash could also be used as fuel when available. Alternatively and more easily, this could have been a natural gas-fired furnace since the thermal oxidizer independently requires that natural gas be available at the plant site. However, natural gas combustion would have emitted fossilderived $\mathrm{CO}_{2}$ to the atmosphere. Ignoring equipment emissions during cultivation, harvesting, and transport, burning biomass causes no net contribution to atmospheric $\mathrm{CO}_{2}$ levels.

\subsubsection{Scenario 5. Depot $-230^{\circ} \mathrm{C}$}

This case is similar to the depot case at $180^{\circ} \mathrm{C}$. The higher thermal treatment temperature produces more combustible offgas, eliminating the need for supplemental natural gas to the regenerative thermal oxidizer. The greater heat output in that unit creates a much hotter effluent stream $-409{ }^{\circ} \mathrm{C}$ compared to only $133{ }^{\circ} \mathrm{C}$ - that allows more preheat of the air to the stoker furnace. The resulting performance improvement allows less wood to be fed to that furnace as fuel.

\subsubsection{Scenario 6. Depot $-270^{\circ} \mathrm{C}$}

In line with the trend of the previous two cases, thermal treatment at $270{ }^{\circ} \mathrm{C}$ creates the greatest amount of flammable gaseous byproducts. Oxidizing them creates sufficient heat to eliminate the need for a stoker furnace to provide heat used in the process. In fact, there is enough surplus heat to generate 39 million BTU/hr (about $11 \mathrm{MW}$ ) of steam for export. This might be sold as steam to a neighboring heatusing process or with the installation of additional power cycle equipment it could generate about 3.5 MW of zero- $\mathrm{CO}_{2}$ electricity.

\subsubsection{Scenario 7. Depot $-230^{\circ} \mathrm{C}-$ Integrated with biorefinery}

This and the next case use the same thermal processing conditions as the previous two cases, but have different thermal and mass integration. In contrast to the first four cases that try to productively use hot gas from the refinery, this case recognizes that the depot's high temperature processing is a net heat generator if the torrefier offgas is oxidized. At $230^{\circ} \mathrm{C}$, the amount of heat available from burning the offgas is not large because only a modest fraction of the wood feed is decomposed to gases. This case also recognizes that if a biorefinery is adjacent, there is no need to duplicate its chip drying equipment. Instead, this case assumes that dried wood chips (at 10\% rather than 30\% moisture content) are fed from the biorefinery directly to the depot torrefier. This final case also shows some equipment for cooling of the torrefied chips before they are stored.

\subsubsection{Scenario 8. Depot $-\mathbf{2 7 0}^{\circ} \mathrm{C}-$ Integrated with biorefinery}

This case is similar to the previous one but with higher temperature processing. The consequence is a much higher flow of torrefier offgas and therefore about eight-fold more heat generation in the furnace. Because the use of predried wood chips means there is no need to create or treat a large dryer offgas stream of minimal fuel value in this process, the smaller flow of furnace flue gas vented to the atmosphere carries away less heat, allowing more heat to be recovered as steam for use in the biorefinery. Because the process off-gas in this scenario is not diluted with large amounts of nitrogen or water vapor, the process furnace operates at high temperature and can produce steam at higher pressures. Such steam is more valuable both for heat-using processes because it is hotter and for work-using processes such as electricity 
generation because of its pressure. It would be feasible to produce steam at two or more pressures to obtain the greatest overall energy recovery while producing the most valuable temperature levels.

\section{EQUIPMENT COST ESTIMATES}

\subsection{Equipment identification and sizing}

For each case, a list of 10-15 major equipment items was compiled along with their major sizing information. For most, sizing was based on the throughput as determined in the Aspen process simulations. For heat exchangers, the temperatures and heat duties from the simulation were used with typical values for overall heat transfer coefficients in similar service to calculate the required exchanger area. The exchangers were sized on the basis of area. Most equipment items were assumed to be fabricated from 304 stainless steel because of the temperatures and the presence of water and organic acids. Where either bins or hoppers are cited, they all also include costs for a rotary valve to dispense solids and a cyclone to capture particulates in any gas vented from the bins or hoppers. It is evident that there are far more than 10-15 items to purchase for a new plant and even if those not listed are small there are many of them; their costs will raise the total equipment cost. However, a significant design effort is required to begin to identify these components and to find cost data for them.

These major equipment items are listed in Appendix 3. The final cost estimates for those items are included there as well as in Appendix 4 where those estimates are derived.

\subsection{Capital cost estimates}

Three sources were used to estimate purchased equipment costs (before installation) for most of these individual components. Two are reference works that include separate sets of correlations and graphs for the cost of a range of equipment items (Couper et al. 2005, Peters et al. 2003), one with an associated web page to facilitate such calculations (Peters et al., www.mhhe.com/engcs/chemical/peters/data). While these references cover a range of equipment types, they are not comprehensive, especially for more complex units such as a regenerative thermal oxidizer or a torrefier intended for biomass. The table in Appendix 4 shows which items could be estimated using these sources and the results obtained for each. In that table, similar equipment was grouped regardless of which scenario it was used in. Specific items can be traced back to their source scenario using the equipment type and the capacity needed.

In some cases the cost correlations had a limited size range over which they were applicable. When the desired unit capacity was larger than the maximum for the correlation, several parallel units each 90$95 \%$ of the maximum size were assumed. In that case, the cost of a single $90-95 \%$ unit was multiplied by the integral number of units required to meet or somewhat exceed the capacity required by the Aspen flow sheets. When the required unit size was only slightly larger (about 10\%) than the maximum of the correlations, the cost of a maximum size unit was used without correction under the assumptions that the equipment could indeed be built slightly larger than indicated and the few percent higher cost of the larger equipment was within the precision of these estimates.

To address the gaps in the availability of cost correlations and to generate a third set of estimates as a check on the results from the two reference works, the cost estimating department at the Idaho National Laboratory was requested to provide estimates as well. That work used both comprehensive cost estimating references (primarily RSMeans Facility Construction Cost Data Manual 2012) and budgetquality quotations from equipment vendors. This information is listed in the rightmost columns of Appendix 4. In many cases several equipment items were similar in scale and only one quote was obtained in that size range. This quotation was used to estimate costs for the similar items using the sixtenths exponent rule, a well-accepted rule of thumb (Peters et al. 2003): 


$$
\frac{\text { Cost of item } A}{\text { Cost of item } B}=\left(\frac{\text { Capacity of item } A}{\text { Capacity of item } B}\right)^{0.6}
$$

In the quote/cost estimator columns of Appendix 4, estimates in black are values from vendor quotes or cost estimating references, while those in red italics were scaled from a similar specific (black) estimate.

The stoker furnace that appears in two cases is a more complex piece of equipment not in the reference books used. Because these units includes significant solids handling capability to feed wood chips and remove ash, using costs of similar-sized oil or natural gas-fired furnaces was not considered to be representative. Instead, the two stoker furnaces were estimated from system cost data (reported in EPA 2007) for a small 100 ton/day furnace burning unspecified biomass with heating value and moisture content similar to wood chips.

Determining the cost of the thermal treatment unit (the torrefier) central to every case was problematic. This is not a common process operation and most vendors do not have publicly available prices, especially not for a large free-standing unit. The required high operating temperature and the need to prevent air intrusion distinguish it from the rotary drum dryer used for moisture removal in the first seven cases. The most analogous common equipment item was considered to be a calciner for minerals processing such as making lime or cement. A used equipment vendor (Perry Videx) provided a quote for an unused surplus calciner of size between the two capacities needed. The estimator collecting this information projected that a new unit would be four times as expensive; that escalated value was then scaled to what was needed for each case. Those scaled costs were judged to be reasonable because they were about $100-170 \%$ of the cost estimated (using unrelated methods) for rotary drum dryers of the same wall area, the basis on which these rotary dryers and thermal treatment units were scaled.

These methods generated costs with different basis years: Peters et al. January 2002; Couper et al. first quarter 2003; EPA 2007; and current vendor quotes mid-2013. All estimates were converted to 2011 dollars using the Chemical Engineering Plant Cost Index. The factors applied to each source were 1.481, $1.458,1.115$, and 1.037 respectively. It is correct that process plant costs were almost $4 \%$ higher in 2011 than they are today. The final estimates were averaged when more than one method was used for an equipment item then rounded to the nearest thousand dollars in partial acknowledgement of the $\pm 30 \%$ accuracy of this type of estimating.

Within each case listed in Appendix 3, there are two or three items that contribute a large fraction of the total cost. In the biorefinery scenarios, the regenerative thermal oxidizer dominates. A deeper analysis of the cost of that process step should be performed to verify the numbers used here. Thermal oxidation makes up over half of the total equipment costs of the $230{ }^{\circ} \mathrm{C}$ case that also uses the largest hot gas flow from the biorefinery. Although the biorefinery generates this gas stream and presumably would itself have to treat and dispose of it in the absence of a biomass thermal treatment process, all the costs of that treatment (the thermal oxidizers or fired heater) and disposal (the exhaust stack) are being carried by the gas-using process. The dryer and torrefier are also large contributors to the cost of the biorefinery cases. While these are more complex items and would be expected to be expensive, the indirect way in which the torrefier cost was estimated should be checked by a more thorough analysis.

In the depot cases the largest costs come from the stoker furnace, thermal treatment unit, thermal oxidizer, and fired heater. The thermal oxidizer is proportionately not as large as in the biorefinery cases because it does not have to treat a large hot gas flow. The stoker furnace stands out by contributing over $25 \%$ of the total capital cost, in part attributable to its mechanical complexity. Further, it is expected to have higher operating costs because of the problems of handling loose solids. A cost/benefit analysis comparing the stoker furnace to a simpler natural gas-fired system could be valuable.

In the final case of a depot at a biorefinery, the saving from not having a separate dryer in this process is offset by the higher cost of the furnace and steam generator because of their greater duties. This case also includes a cooling system for the torrefied product so it can be stored in the open air without risk of 
combustion from its high temperature leaving the process. That cooling system is relatively inexpensive compared to the overall system cost.

\section{FACILITY COST ESTIMATES}

\subsection{Total capital costs}

1. The total capital cost for purchased major equipment for each case is shown in Appendix 3. The biorefinery cases range from $\$ 12-24$ million, while the four depot-scale cases are all close to $\$ 4.9$ million. These equipment costs can be converted to tot al plant investment costs by estimating the other related cost components as experience-derived fractions of the purchased equipment cost. Such a calculation appears in Appendix 5, which shows a page from the economics spreadsheet at the Peters et al. web site (http://highered.mcgraw-hill.com/sites/dl/free/0072392665/53825/CostandEvaluation111103.xls). That calculation sheet provides three sets of factors depending on the materials being handled - solids, liquids/gases, or both. These biomass thermal treatment processes are solids-only processing because there is no significant further processing of any gases generated. The results for all cases are summarized in Table 2. The fixed capital costs are associated with building the plant and its appurtenances; the total capital cost includes working capital to operate it.

Table 2. Total capital cost of the alternative cases

\begin{tabular}{|l|c|c|c|}
\hline & $\begin{array}{c}\text { Equipment } \\
\text { cost (\$M) }\end{array}$ & $\begin{array}{c}\text { Fixed capital } \\
\text { cost (\$M) }\end{array}$ & $\begin{array}{c}\text { Total capital } \\
\text { cost (\$M) }\end{array}$ \\
\hline BIOREFINERY CASES & & & \\
\hline $150^{\circ} \mathrm{C}$ drying & 12.64 & 55.2 & 64.9 \\
\hline $180^{\circ} \mathrm{C}$ semi-reactive drying & 17.87 & 78.0 & 91.8 \\
\hline $230^{\circ} \mathrm{C}$ torrefaction & 23.66 & 103.3 & 121.5 \\
\hline $230^{\circ} \mathrm{C}$ torr. with fired heater & 12.45 & 54.4 & 64.0 \\
\hline & & & \\
\hline DEPOT CASES & & & 21.4 \\
\hline $180^{\circ} \mathrm{C}$ semi-reactive drying & 4.91 & 21.1 & 24.9 \\
\hline $230^{\circ} \mathrm{C}$ torrefaction & 4.84 & 21.4 & 25.1 \\
\hline $270^{\circ} \mathrm{C}$ torrefaction & 4.89 & 13.4 & 15.8 \\
\hline $230^{\circ} \mathrm{C}$ torr. at biorefinery & 2.42 & 22.1 & 25.9 \\
\hline $270{ }^{\circ} \mathrm{C}$ torr. at biorefinery & 5.05 & & \\
\hline
\end{tabular}

\subsection{Scaling of plant cost with size}

The cases in this report include only two different production rates of thermally treated wood chips, 20 and 100 tons per day. The cost estimates for them can be extended to plants running the same process at greater or smaller capacity by using the six-tenths exponent rule first introduced for equipment costing:

$$
\frac{\text { Cost of facility } A}{\text { Cost of facility } B}=\left(\frac{\text { Capacity of facility } A}{\text { Capacity of facility } B}\right)^{0.6}
$$

For example, a plant of 40 ton/hour capacity, twice as large as the depots of this report, would be expected to cost about $(40 / 20)^{0.6}=1.52$ times as much, illustrating the concept of economy of scale. This expression is applicable when the equipment in a process is all made proportionately larger or smaller to 
achieve a different capacity. It does not apply if higher capacities are achieved by building multiple small plants at the same site. While there are some savings in design and common area costs when building parallel trains, the cost for capacity achieved in that way will be roughly linear with the number of trains.

\subsection{Comparison to other facility costs}

With torrefaction not being a widely used process, the academic and trade literature have a dearth of capital and operating cost data for complete plants. In the course of this work two examples were identified. Agri-Tech Producers, LLC (www.agri-techproducers.com) markets a package system that makes 5 ton/hour of torrefied wood. It includes solids handling between process steps and incorporates a furnace for offgas treating and heat generation, but does not include any feed or product storage or solids handling or loading equipment. The listed price for it is \$5 million. As a second cost comparison, HM3 Energy, Inc. (HM3energy.com) explained in a private communication that their standard torrefaction system using wood waste has a capacity of 11 ton/hour and costs about $\$ 20$ million.

These cost figures can be scaled for comparison to the results of this report (Table 3). While there is a wide spread of costs at the 20 ton/hour scale, the total facility cost estimated in this work is bracketed by the others. The lack of detailed information on what is included in their cost numbers prevents an attempt to refine these estimates. Nonetheless, this report's result is consistent with the available industry data.

Table 3. Comparison of plant costs

\begin{tabular}{|l|c|c|c|}
\hline \multicolumn{1}{|c|}{ Process provider } & $\begin{array}{c}\text { Production rate } \\
\text { (ton/hour) }\end{array}$ & $\begin{array}{c}\text { Fixed } \\
\text { capital cost } \\
\text { (\$ million) }\end{array}$ & $\begin{array}{c}\text { Capital cost scaled } \\
\text { to 20 ton/hour } \\
\text { (\$ million) }\end{array}$ \\
\hline Agri-Tech Producers & 5 & 5 & 11.5 \\
\hline $\mathrm{HM}$ Energy & 11 & 20 & 28.6 \\
\hline This report, depot case at $230^{\circ} \mathrm{C}$ & 20 & 21.1 & 24.9 \\
\hline
\end{tabular}

There are also research reports on combined torrefaction and pelletization of wood. Pelletization requires additional equipment for size reduction and extrusion that makes it not directly comparable to a process for torrefaction alone. One such system (van der Stelt et al. 2011) has 56,000 metric tons/year of torrefied pellet production from a European plant design costing 7.4 million euros (about $\$ 9.6$ million). The 0.6 exponent rule then implies a cost of $\$ 13.6$ million for a plant of 100,000 metric tons annual capacity. Another reported design (Pirraglia et al. 2013) produces 100,000 metric tons/year in the US at a capital cost of $\$ 49.5$ million. At equivalent capacity, its capital cost is an unusually large $364 \%$ of the first example. However, the larger US system had four parallel trains of equipment rather than using single large items and therefore sacrificed some economy of scale; this would explain a projected cost $174 \%$ of the European design but not the actual result two-fold higher than this. A third torrefaction/pelletization report (Svanberg et al. 2013) finds the capital cost for a comprehensive facility design producing 200,000 metric tons/year to be 45.5 million euros (about $\$ 59$ million). They note the problem of parallel trains affecting the scalability of costs in large plants, but suggest that parallel trains only become necessary above the 200,000 ton/year of their study. Scaling their capital cost back to 100,000 ton/year using their suggested power law exponent of 0.7, their plant cost becomes $\$ 28$ million. This nearly four-fold range of costs - 13.6, 28, and 49.5 million dollars - for the same plant capacity, as well as their range comparable to the torrefier plants in Table 3 despite being more complex and having five times more capacity than them, suggest caution in the use of any published costs for these types of processes. 


\section{COST OF THERMAL TREATMENT}

\subsection{Feedstock and energy costs}

Using the Aspen flow sheets it is possible to generate estimates for feed material and energy costs. Only the four 20 ton/hour depot cases will be compared here. The larger biorefinery-scale cases depend greatly on use of the biorefinery hot gas that might not be readily transportable to the depot and that is impossible to independently price because it is otherwise a valueless waste stream from that facility. If the biorefinery and torrefaction depot are owned and operated by the same company, there is great latitude in what the transfer price of the gas stream might be.

The depot's steam selling price has a similar difficulty because the heat in it is a waste stream as far as biomass processing is concerned. Based on typical electricity cost of $\$ 0.06 / \mathrm{kWh}(\$ 17.57$ per million BTU of electricity) and 33\% thermal efficiency of generation, a combined heat and power plant can generate steam at a cost near $\$ 6 /$ million BTU. This can be viewed as a minimum price that includes all operating costs and also substantial economies of scale for a full-size power plant. If such a combined heat and power plant was not nearby, a user of heat would have to build and operate a relatively small and therefore expensive (per unit of production) steam boiler or direct-fired system using natural gas that currently costs $\$ 4$ per million BTU. Based on these results a steam selling price of $\$ 10$ per million BTU was chosen, somewhat arbitrarily, to reflect the alternative cost of a small boiler or the chance that future natural gas prices will be substantially above current low values.

In the depot cases making the same amount of torrefied product at three different temperatures, there is a shift from supplying energy as natural gas or wood fed directly into burners to using torrefaction offgas obtained from more severe treatment of an increased feed rate of wood chips (Table 4). Changes in the temperature and flow rate of the regenerative thermal oxidizer's or the furnace's flue gas and the temperature of the solid product explain the small differences in the net energy input of the cases.

Table 4. Energy feeds to depot-scale processes making 20 ton per hour of product

\begin{tabular}{|c|c|c|c|c|c|c|}
\hline \multirow{2}{*}{$\begin{array}{c}\text { Thermal } \\
\text { treatment } \\
\text { temperature }\left({ }^{\circ} \mathrm{C}\right)\end{array}$} & $\begin{array}{c}\text { Energy flows (million BTU/hour) } \\
\text { Wood chips to } \\
\text { process* }\end{array}$ & $\begin{array}{l}\text { Wood chips } \\
\text { to furnace* }\end{array}$ & $\begin{array}{c}\text { Natural gas } \\
\text { to oxidizer }\end{array}$ & $\begin{array}{c}\text { Steam } \\
\text { export }\end{array}$ & $\begin{array}{c}\text { Water vapor } \\
\text { in flue gas** }\end{array}$ & $\begin{array}{c}\text { Net energy } \\
\text { input }\end{array}$ \\
\hline 180 & 259 & 22 & 2.3 & -- & $(19)$ & 264 \\
\hline 230 & 272 & 18 & -- & -- & $(19)$ & 271 \\
\hline 230 & $273(10 \% \mathrm{MC})$ & -- & -- & $(7)$ & $(5)$ & 261 \\
\hline 270 & 335 & -- & -- & $(39)$ & $(22)$ & 274 \\
\hline 270 & $336(10 \% \mathrm{MC})$ & -- & -- & $(60)$ & $(6)$ & 270 \\
\hline
\end{tabular}

*Assumes 4500 BTU/lb HHV for $30 \%$ moisture content wood chips and 5800 BTU/lb for $10 \%$ MC wood chips. ** Corrects for water condensation presumed in the HHV values

In addition to these thermal energy costs, the cost estimating equipment lists call out about $450 \mathrm{HP}$ of motors for each depot flow sheet. Their power draw during operation will be less than their rated maximum capacity, but there will be other motors in the plant that are not identified. At a power price of $\$ 0.06 / \mathrm{kWh}, 450 \mathrm{HP}$ of electricity costs $\$ 20$ per hour that is assumed to be the same for all of the cases. 


\subsection{Cost per unit of production}

A thorough cost estimate for thermal treatment requires an accurate capital cost estimate as well as a breakdown of a variety of operating and financial costs. These are not available in any detail for the processes of this report. However, the major cost elements can be estimated to approximate the processing cost per unit of product (Table 5). In doing this, an annual operating rate corresponding to 7500 hours per year ( $85.6 \%$ availability) is assumed.

Most of the items in this table have been discussed earlier. The first item, for additional feed of wood chips, is a result of the greater conversion of wood to offgas at higher temperatures. To produce the same amount of thermally treated wood, a larger amount of green wood chips must be fed to the higher temperature processes. This expense item reflects the incremental feed of wood compared to the feed rate for the $180{ }^{\circ} \mathrm{C}$ case that has $99 \%$ yield of treated biomass from the wood feed (Table 1).

Table 5. Operating cost of depot processes

\begin{tabular}{|c|c|c|c|c|c|c|}
\hline \multirow[b]{2}{*}{ Cost components } & \multirow[b]{2}{*}{ Cost basis } & \multicolumn{5}{|c|}{ Treatment costs (\$ million/year) } \\
\hline & & $\begin{array}{l}\text { Treatment } \\
\text { at } 180^{\circ} \mathrm{C}\end{array}$ & $\begin{array}{l}\text { Treatment } \\
\text { at } 230^{\circ} \mathrm{C}\end{array}$ & $\begin{array}{l}\text { Treatment } \\
\text { at } 270^{\circ} \mathrm{C}\end{array}$ & $\begin{array}{l}230^{\circ} \mathrm{C} \\
\text { using dried } \\
\text { wood }\end{array}$ & $\begin{array}{c}270^{\circ} \mathrm{C} \\
\text { using dried } \\
\text { wood }\end{array}$ \\
\hline $\begin{array}{l}\text { Wood chips (lower } \\
\text { product yield at higher } \\
\text { temp.) }\end{array}$ & $\$ 25 /$ dry ton & & 0.2 & 1.1 & 0.2 & 1.1 \\
\hline $\begin{array}{l}\text { Wood chips (as stoker } \\
\text { furnace fuel) }\end{array}$ & $\$ 25 /$ dry ton & 0.3 & 0.3 & & & \\
\hline Natural gas & \$4/million BTU & 0.1 & & & & \\
\hline Electricity & $\$ 0.06 / \mathrm{kWh}$ & 0.2 & 0.2 & 0.2 & 0.2 & 0.2 \\
\hline Operating labor* & $\begin{array}{l}\$ 50 / \text { hour/person } \\
\text { with indirect costs }\end{array}$ & 1.8 & 1.8 & 1.8 & 1.8 & 1.8 \\
\hline $\begin{array}{l}\text { Maintenance labor and } \\
\text { materials }\end{array}$ & $7 \%$ cap. cost/year & 1.8 & 1.7 & 1.8 & 1.1 & 1.8 \\
\hline Steam sales & \$10/million BTU & & & (2.9) & $(0.6)$ & $(4.5)$ \\
\hline OPERATING EXPENSES & & 4.2 & 4.3 & 2.0 & 2.7 & 0.4 \\
\hline Capital recovery charge & $12 \%$ cap. cost/year & 3.0 & 3.0 & 3.0 & 1.9 & 3.2 \\
\hline TOTAL EXPENSES & & 7.2 & 7.3 & 5.0 & 4.6 & 3.6 \\
\hline Thermal processing cost & & $\$ 28 /$ ton & \$29/ton & $\$ 13 /$ ton & \$18/ton & $\$ 3 /$ ton \\
\hline $\begin{array}{l}\text { Thermal processing cost } \\
\text { with capital recovery }\end{array}$ & & \$48/ton & $\$ 49 /$ ton & $\$ 33 /$ ton & $\$ 31 /$ ton & $\$ 24 /$ ton \\
\hline
\end{tabular}

* Estimated to be 4 workers/shift using Peters et al. table 6-13 and figure 6-9. Svanberg et al. (2013) estimate in their Figure 2 a need for 18 workers at a 150,000 ton/year plant, equal to four shifts of 4.5 workers each.

In the two lower temperature cases, the thermal processing cost is $\$ 28-29$ per ton of product wood. Inclusion of a return on the capital invested in the thermal treatment plant raises the processing cost by $\$ 20$ per ton. There might also be a difference between these cases in the revenue from sales of solid product with different extents of thermal treatment, but this is not considered in this table. 
In the two $270{ }^{\circ} \mathrm{C}$ temperature cases the projected processing cost is dramatically reduced by the sale of steam. However, the price at which a neighboring user might buy the steam is uncertain because of a possible lack of local competition for this byproduct (other than the biorefinery) and because the steam is available only when the thermal processing plant operates, 7500 hours or about $86 \%$ of the year. Table 2 shows the effect of this factor on the case using dried wood chips from the biorefinery. If there was no steam revenue at all, the $270{ }^{\circ} \mathrm{C}$ cases would have a processing cost of $\$ 33 /$ ton of product, somewhat greater than the other two cases. At $\$ 4$ per million BTU, the same price as natural gas, the net processing cost is $\$ 21.25$ per ton.



Figure 2. Effect of steam price on net thermal processing cost at $270{ }^{\circ} \mathrm{C}$

\section{REFERENCES}

Couper JR, Penney WR, Fair JR, Walas SM (2005), Chemical Process Equipment - Selection and Design, 2nd ed., Gulf Professional Publishing, Burlington MA USA.

Dutta A, Talmage M, Hensley J, Worley M, Dudgeon D, Barton D, Groenendijk P, Ferrari D, Stears B, Searcy EM, Wright CT, and Hess JR, Process Design and Economics for Conversion of Lignocellulosic Biomass to Ethanol, NREL Technical Report TP-5100-51400. May 2011

US Environmental Protection Agency (EPA), Biomass Combined Heat and Power Catalog of Technologies, US EPA CHP Partnership, September 2007, p. 80-85

Peters MS, Timmerhaus KD, West RE (2003), Plant Design and Economics for Chemical Engineers, $5^{\text {th }}$ ed., McGraw Hill, New York. Supplementary web site: www.mhhe.com/engcs/chemical/peters/data accessed Sept 28, 2013.

Phanphanich M, Mani S (2011), Impact of torrefaction on the grindability and fuel characteristics of forest biomass. Bioresource Technol. 102, 1246-1253.

Pirraglia A, Gonzalez R, Saloni D, Denig J (2013), Technical and economic assessment for the production of torrefied ligno-cellulosic biomass pellets in the US, Energy Conv Management, 66, 153-164.

Svanberg M, Olofsson I, Floden J, Nordin A (2013). Analysing biomass torrefaction supply chain costs, Bioresource Technol., 142, 287-296.

van der Stelt MJC, Gerhauser H, Kiel JHA, Ptasinski KJ (2011), Biomass upgrading by torrefaction for the production of biofuels: a review, Biomass Bioenergy, 35, 3748-3762.

Westover TL, Phanphanich M, Clark ML, Rowe SR, Egan SE, Zacher AH, and Santosa D, Impact of thermal pretreatment on the fast pyrolysis conversion of southern pine, Biofuels 4, 45-61 (2013). 
Appendix 1

Schematic Process Flow Diagrams 


\section{Scenario 1 - Refinery - Southern Pine - Drying at $150^{\circ} \mathrm{C}$}

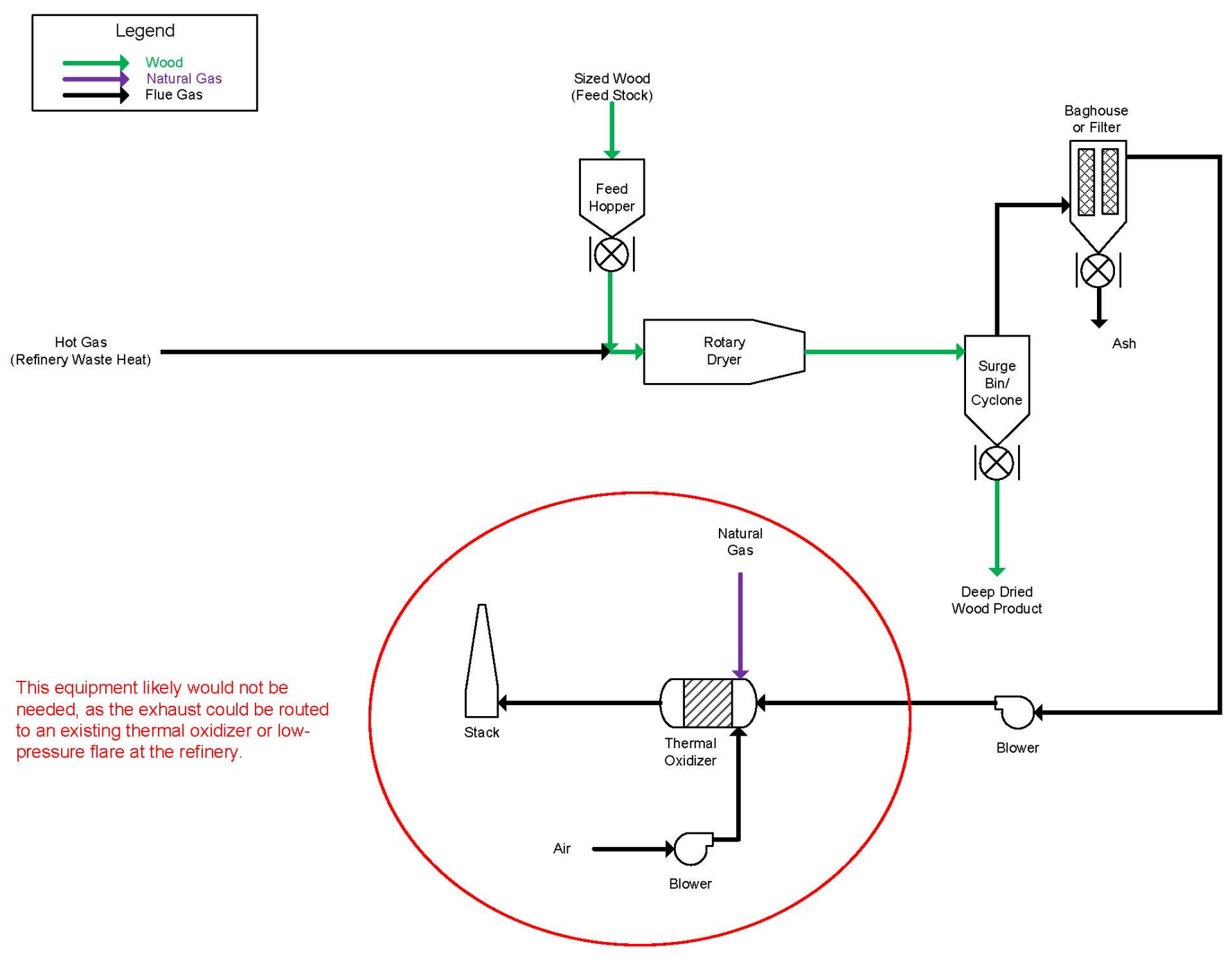




\section{Scenario 2 - Refinery - Southern Pine - Torrefaction at $180^{\circ} \mathrm{C}$}

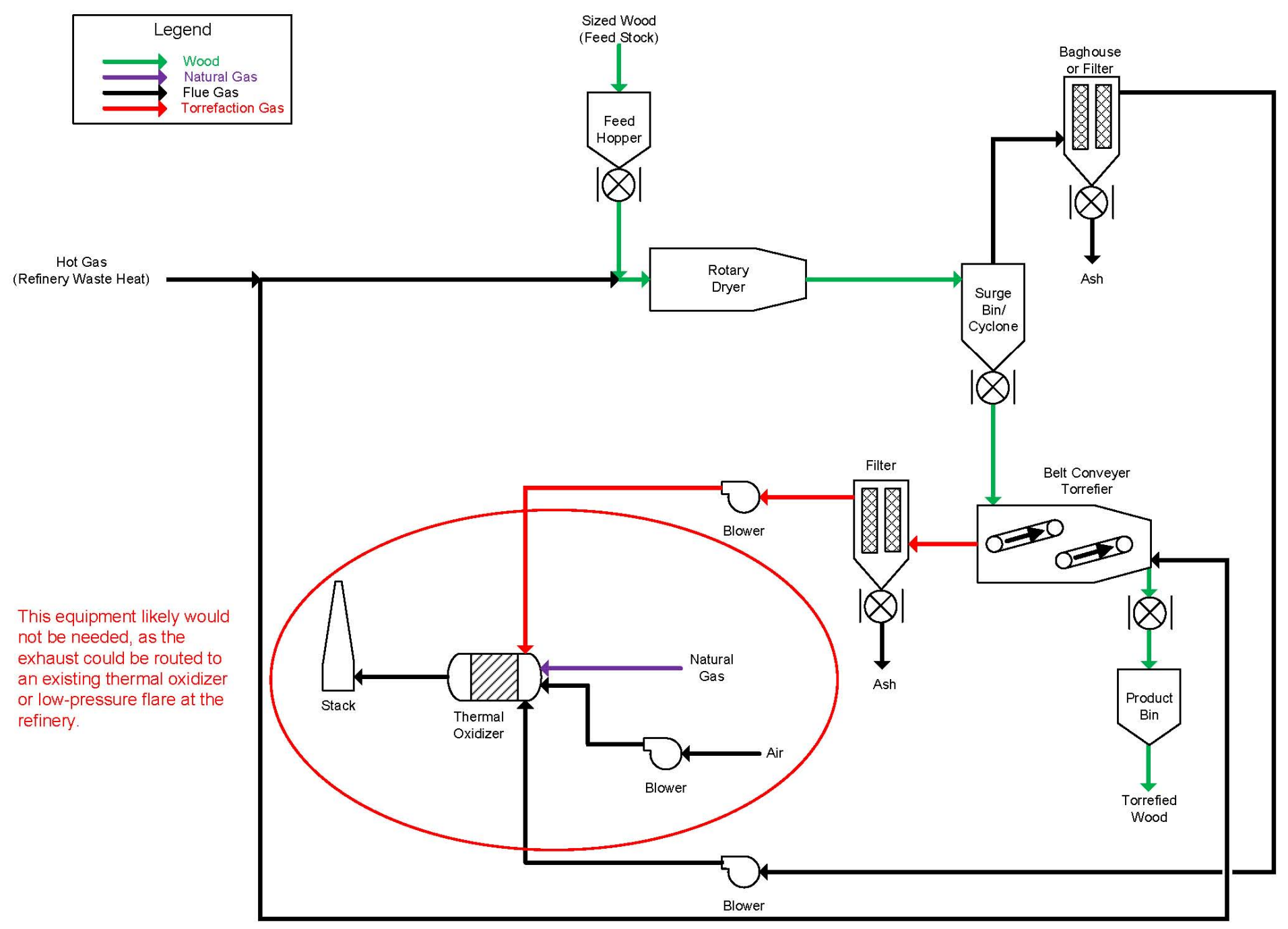


Scenario $3 \mathrm{~A}$ - Refinery - Southern Pine - Torrefaction at $230^{\circ} \mathrm{C}$

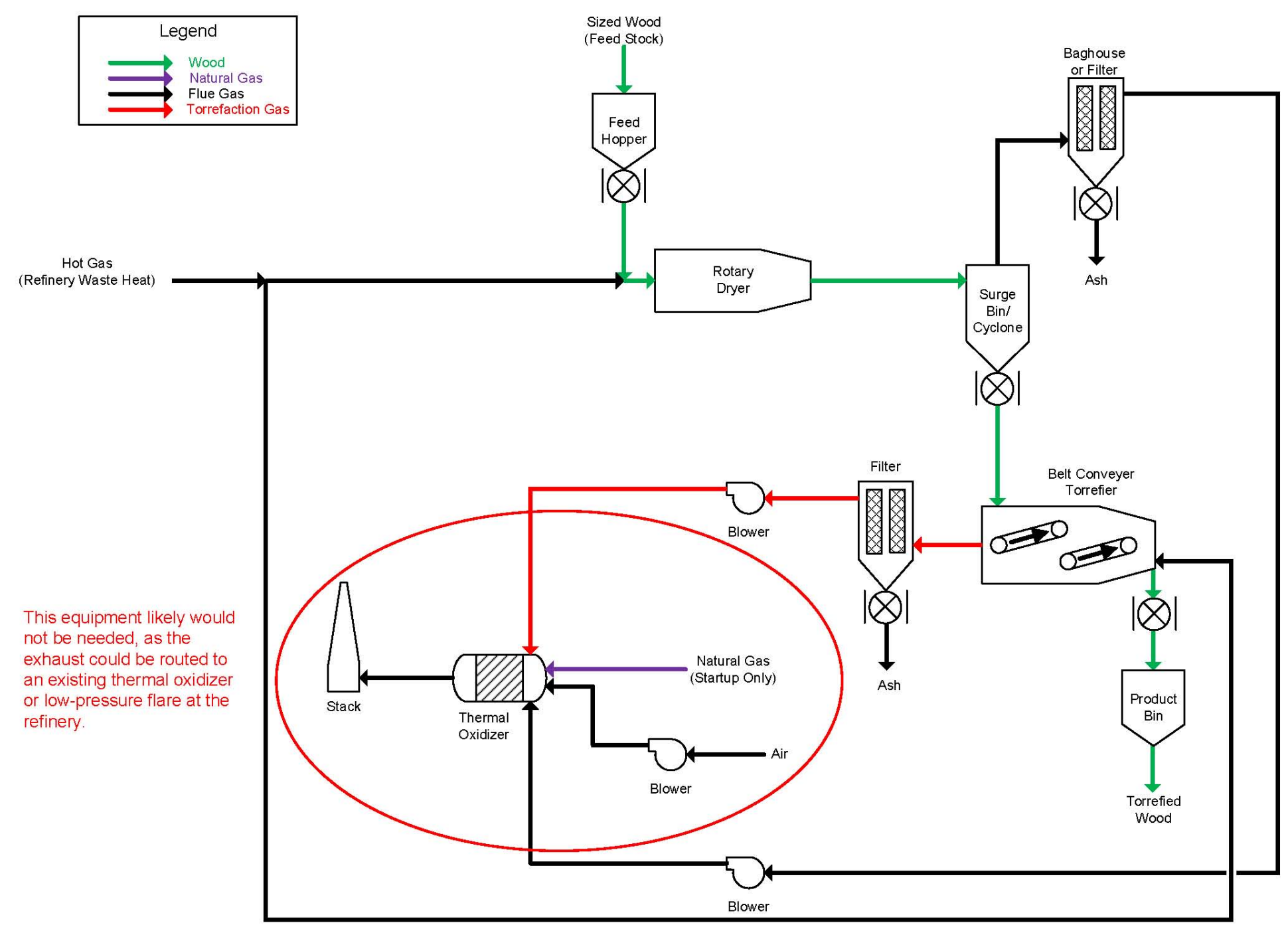


Scenario 3B - Refinery - Southern Pine - Torrefaction at $230^{\circ} \mathrm{C}$ (With Fired Heater)

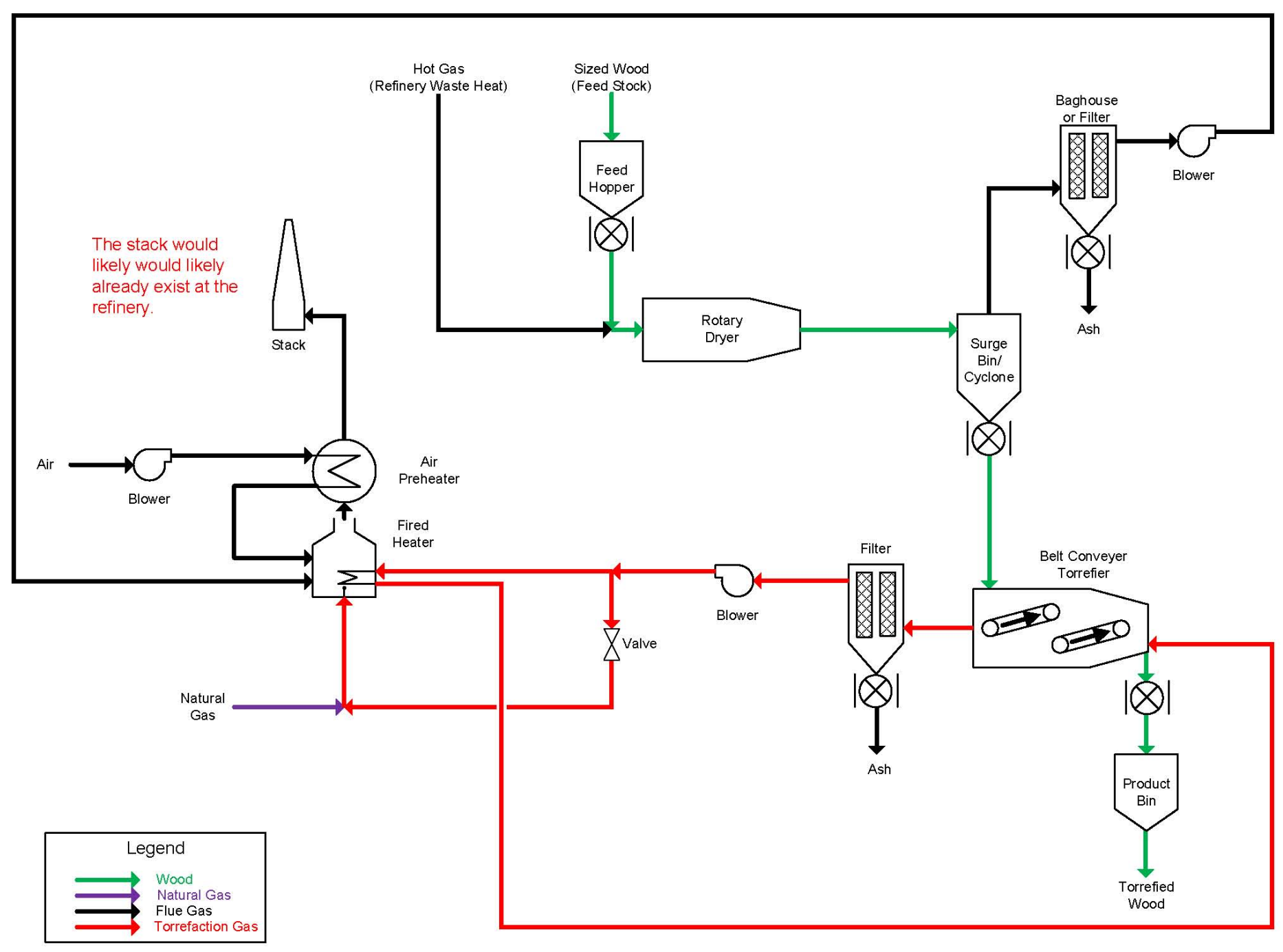


Scenario 4 - Depot - Southern Pine - Torrefaction at $180^{\circ} \mathrm{C}$

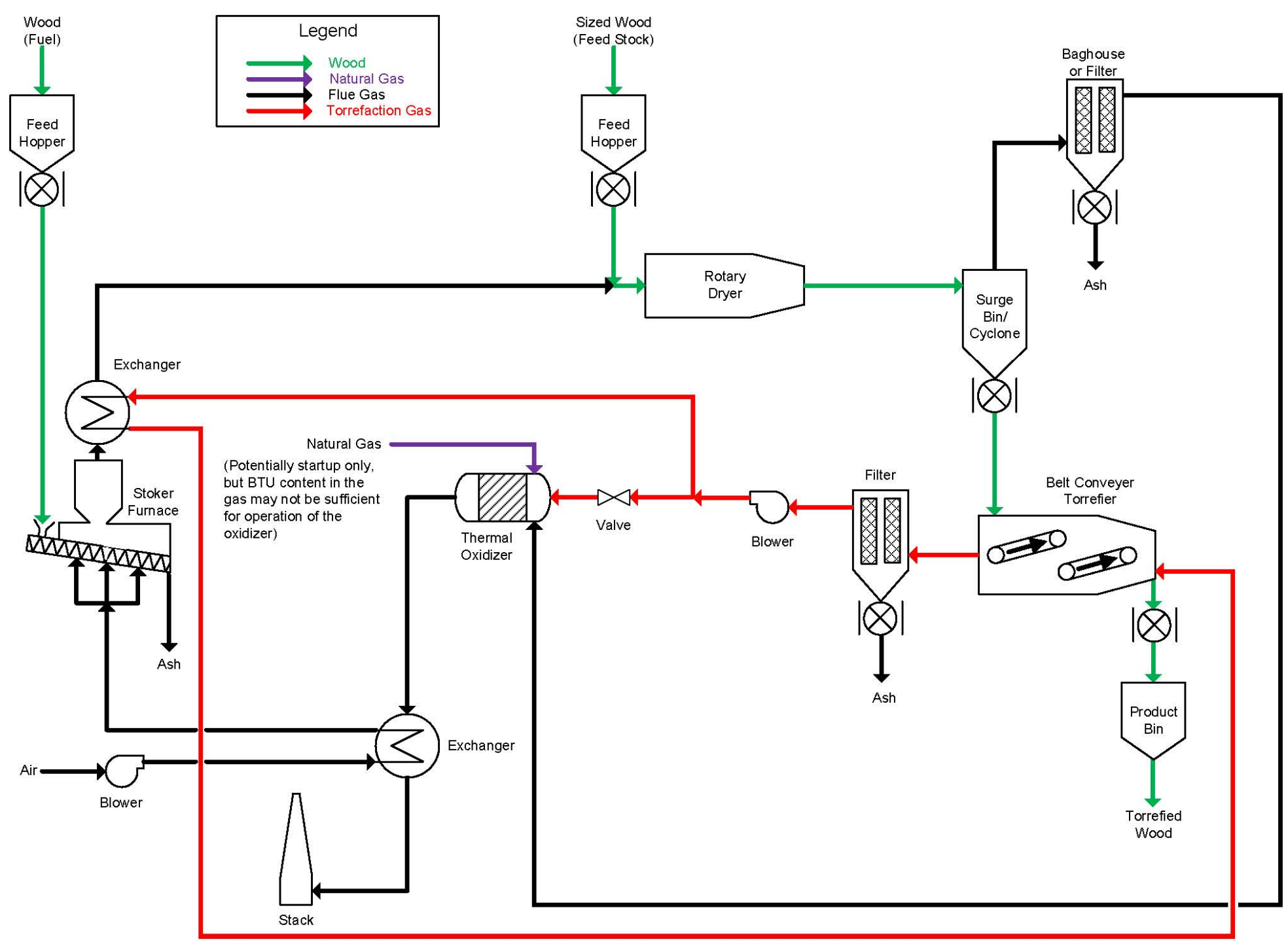




\section{Scenario 5 - Depot - Southern Pine - Torrefaction at $230^{\circ} \mathrm{C}$}

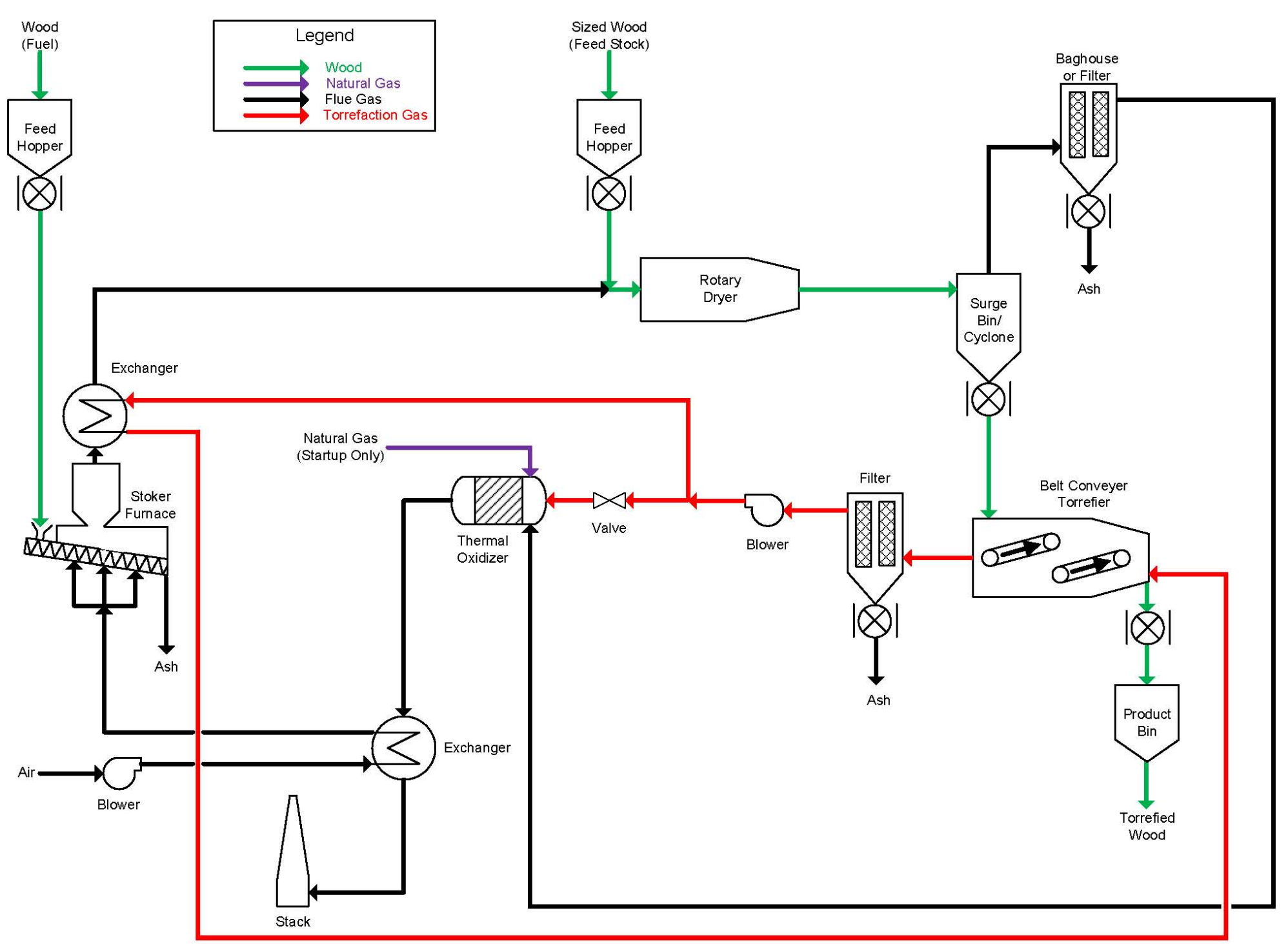


Scenario 6 - Depot - Southern Pine - Torrefaction at $270^{\circ} \mathrm{C}$

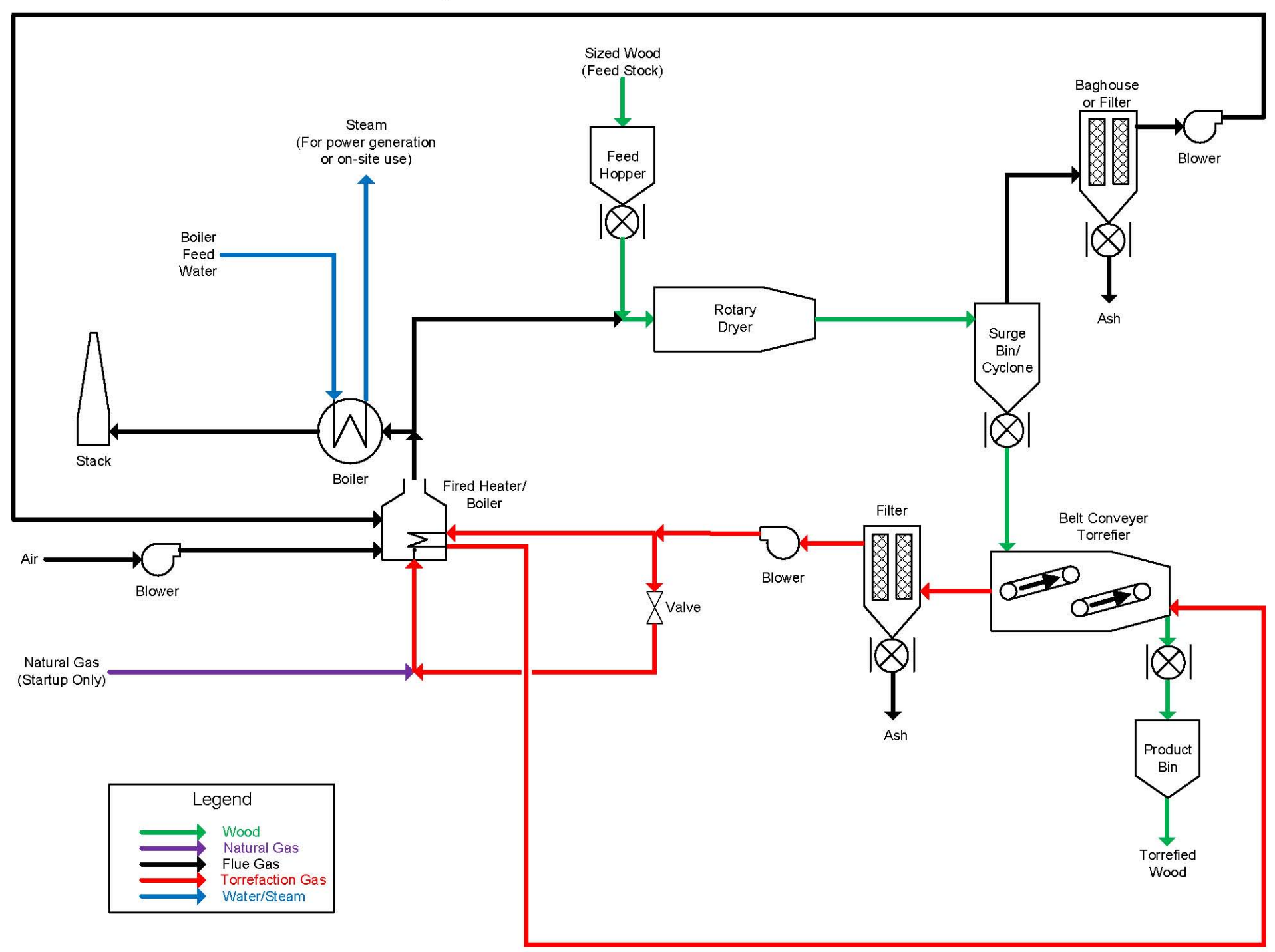




\section{Scenario 7. Depot $-230^{\circ} \mathrm{C}$ - at biorefinery}

\section{Scenario 8. Depot $-270^{\circ} \mathrm{C}$ - at biorefinery}

Schematic diagrams not available.

See flow sheets in Appendix 2. 
Appendix 2

Detailed Simulation Results 
Scenario 1 - Refinery - Thermal Treatment of Southern Pine @ 150 Degrees C




Scenario 2 - Refinery - Torrefaction of Southern Pine @ 180 Degrees C

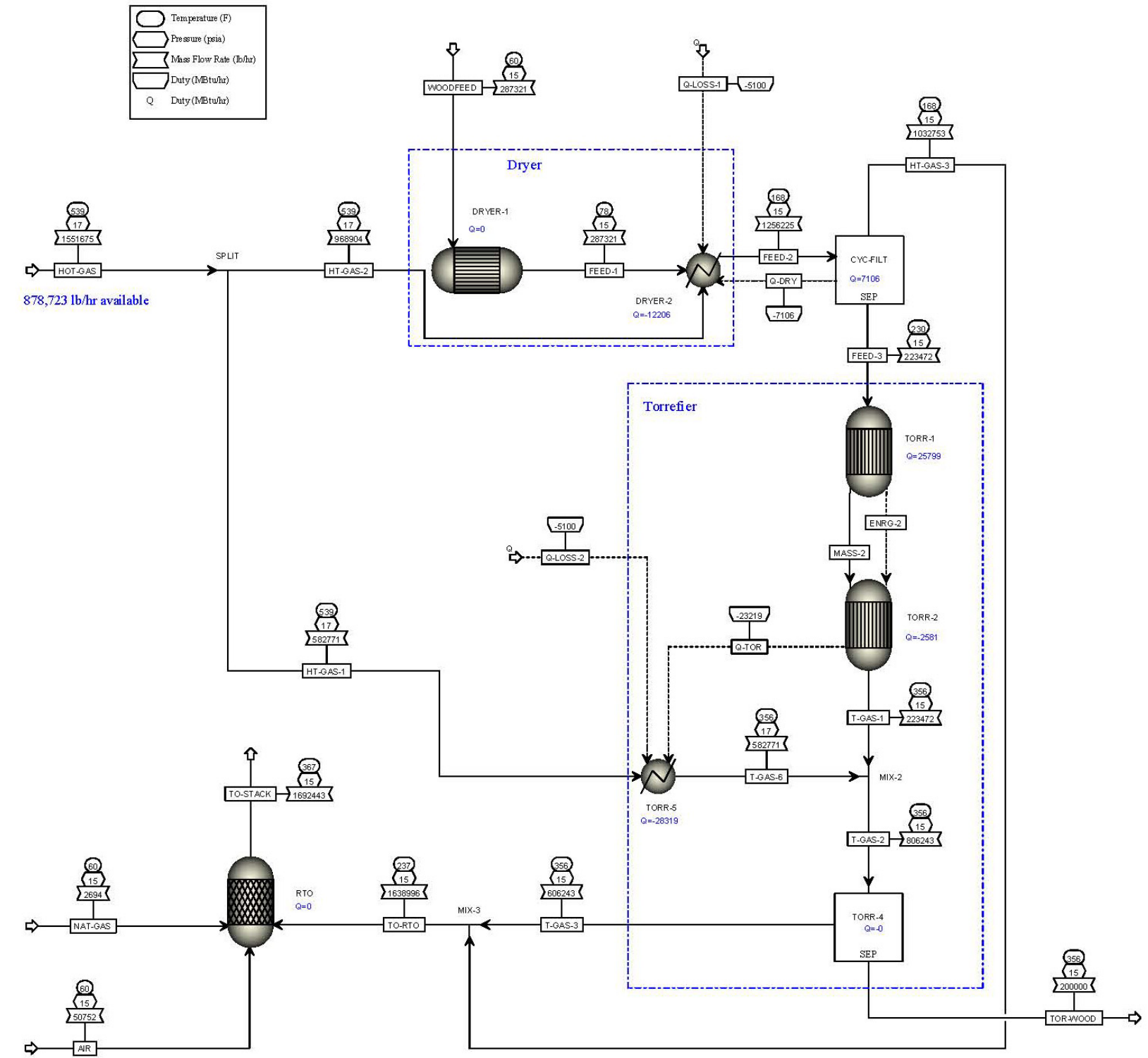


Scenario 3A - Refinery - Torrefaction of Southern Pine @ 230 Degrees C

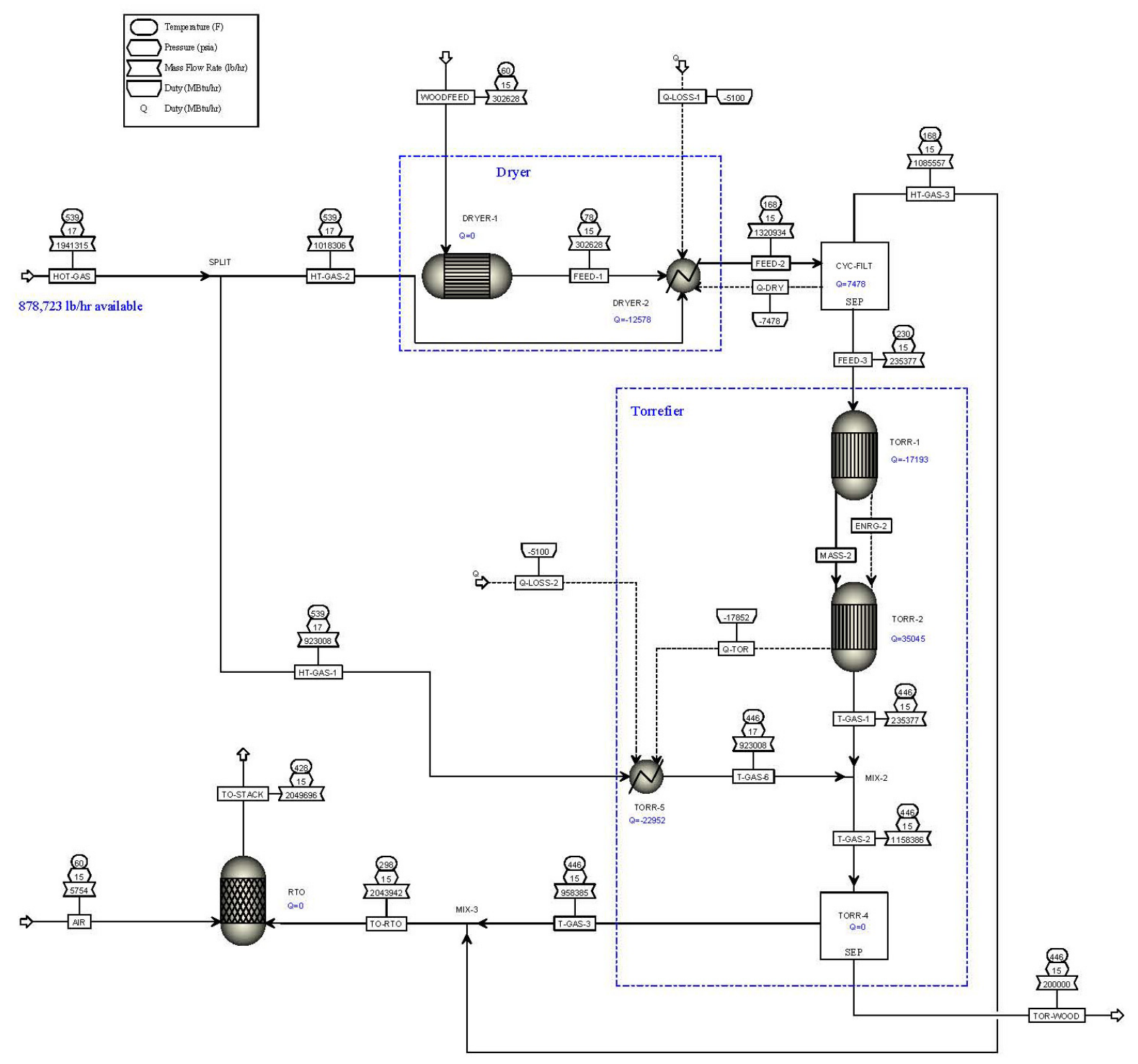


Scenario 3B - Refinery (Fired Heater) - Torrefaction of Southern Pine @ 230 Degrees C




Scenario 4 - Depot - Torrefaction of Southern Pine @ 180 Degrees C

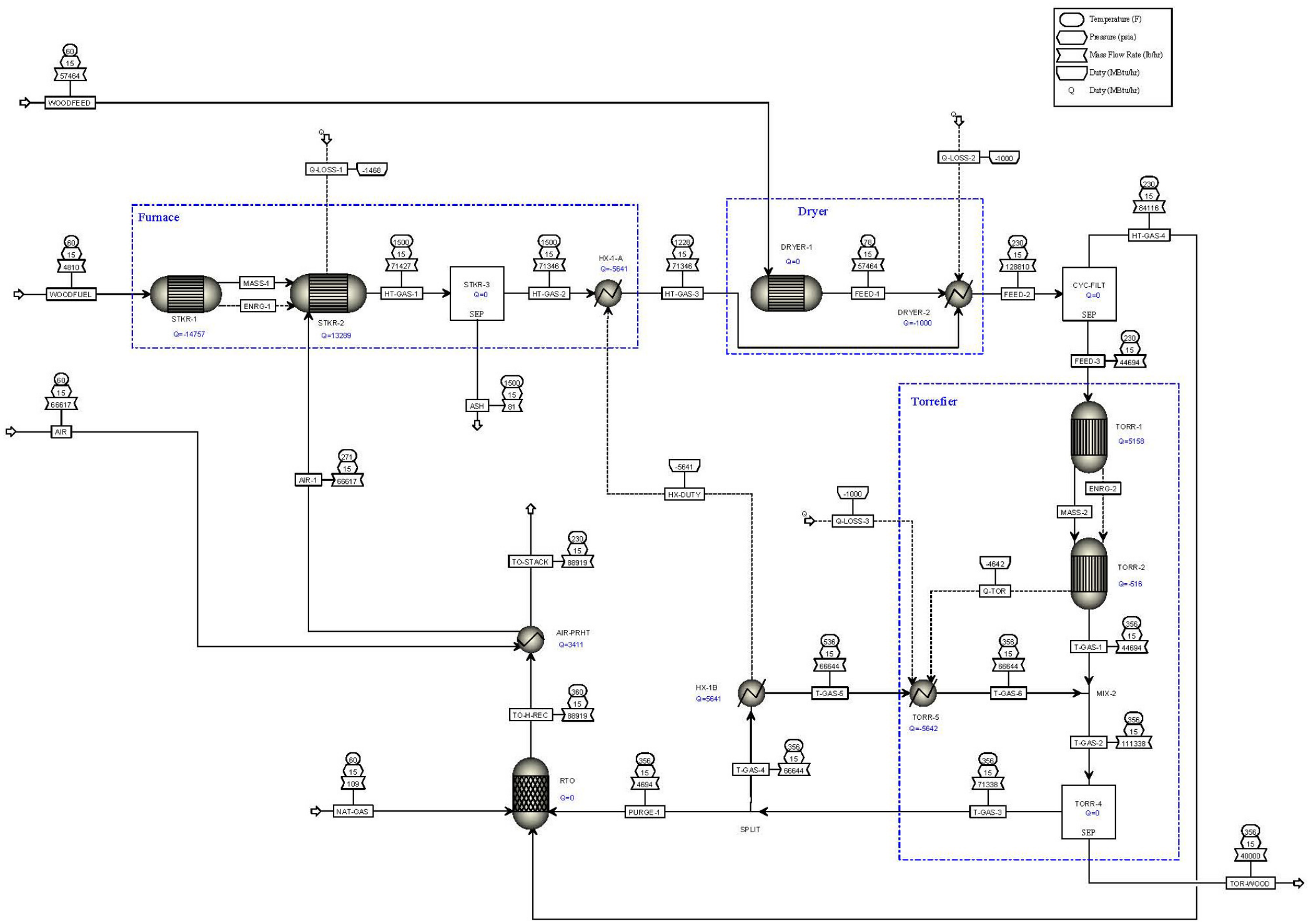


Scenario 5 - Depot - Torrefaction of Southern Pine @ 230 Degrees C

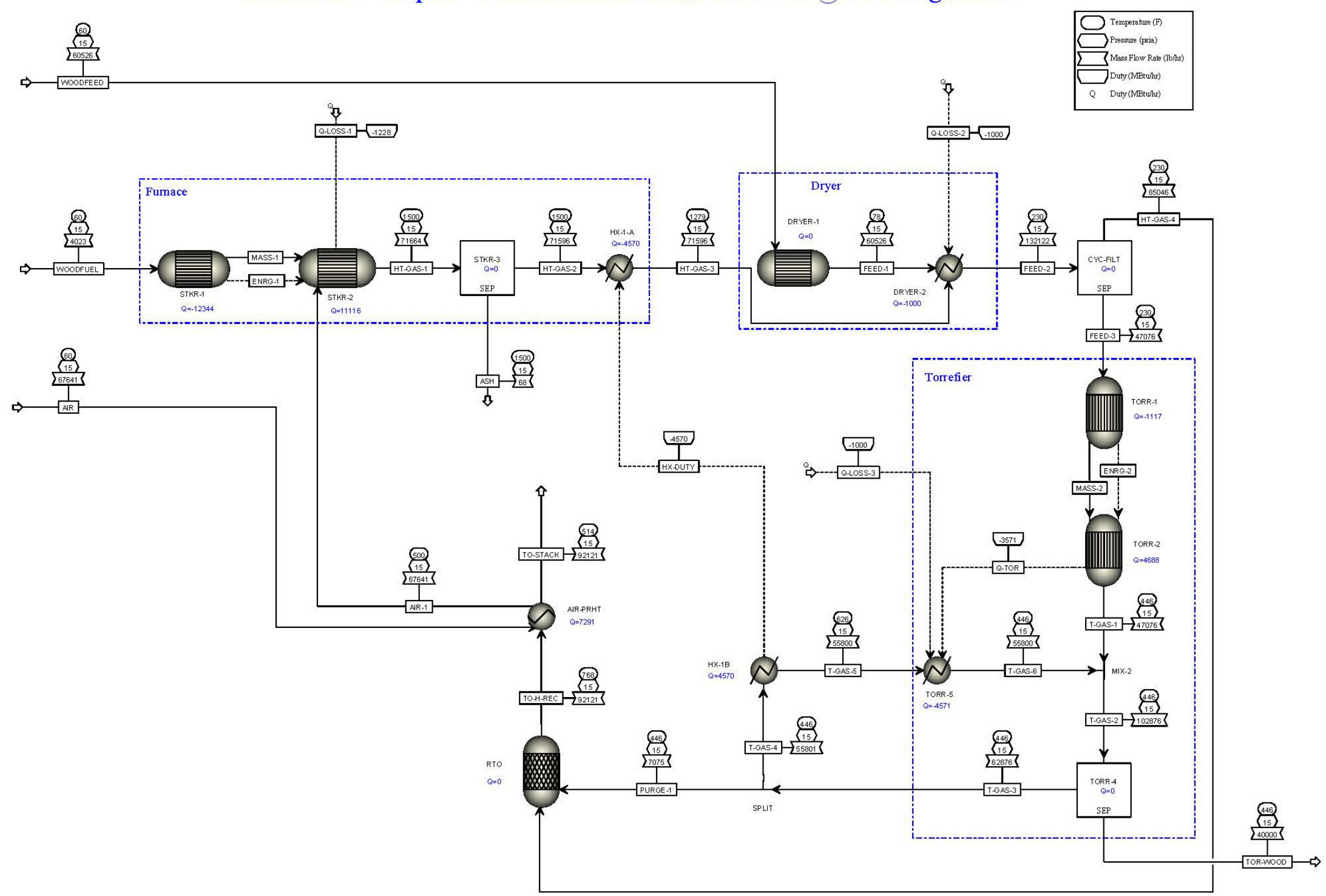


Scenario 6 - Depot - Torrefaction of Southern Pine @ 270 Degrees C

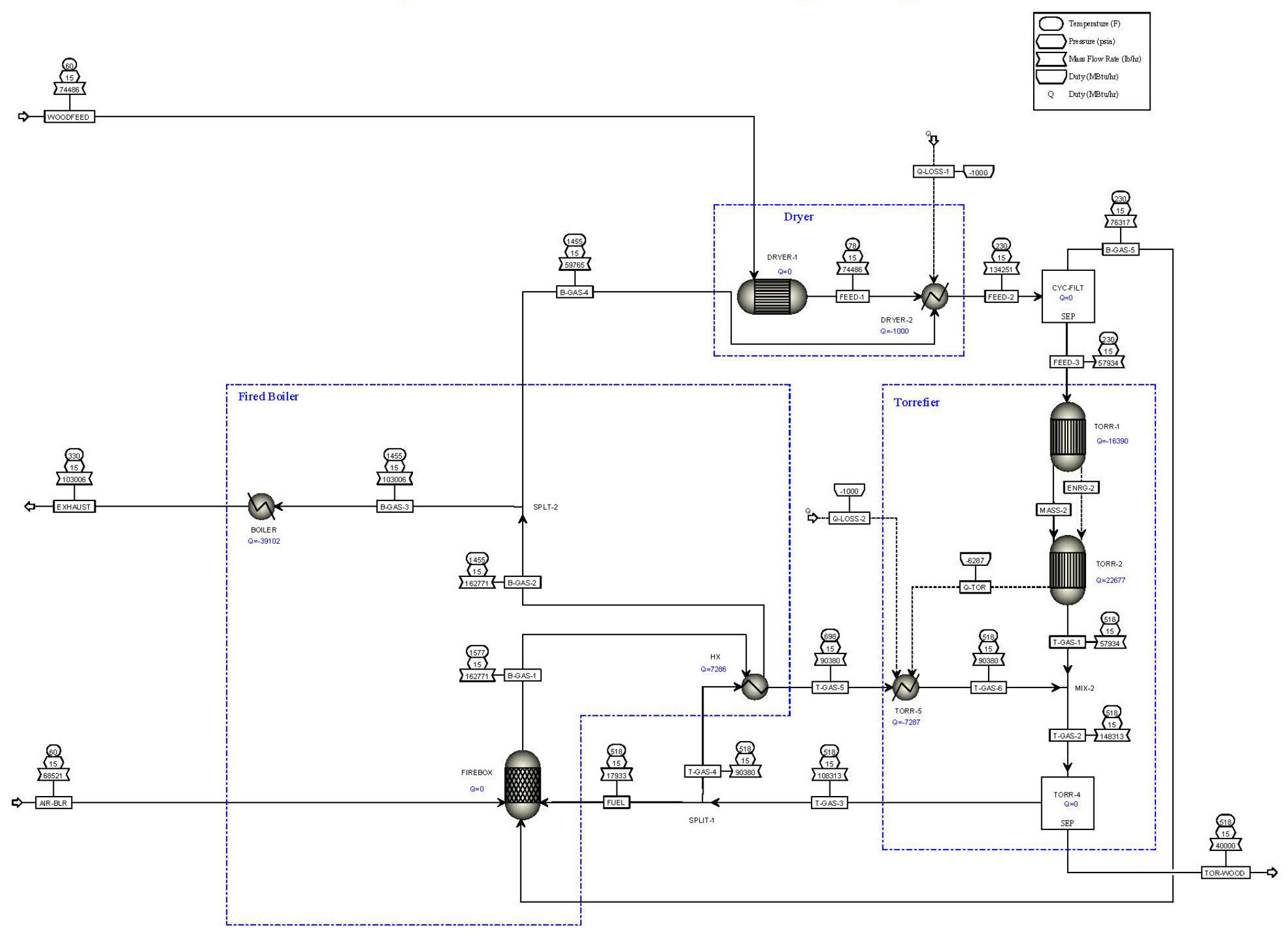


Scenario 7. Depot-Biorefinery Thermal Integration $230 \operatorname{deg}$ C

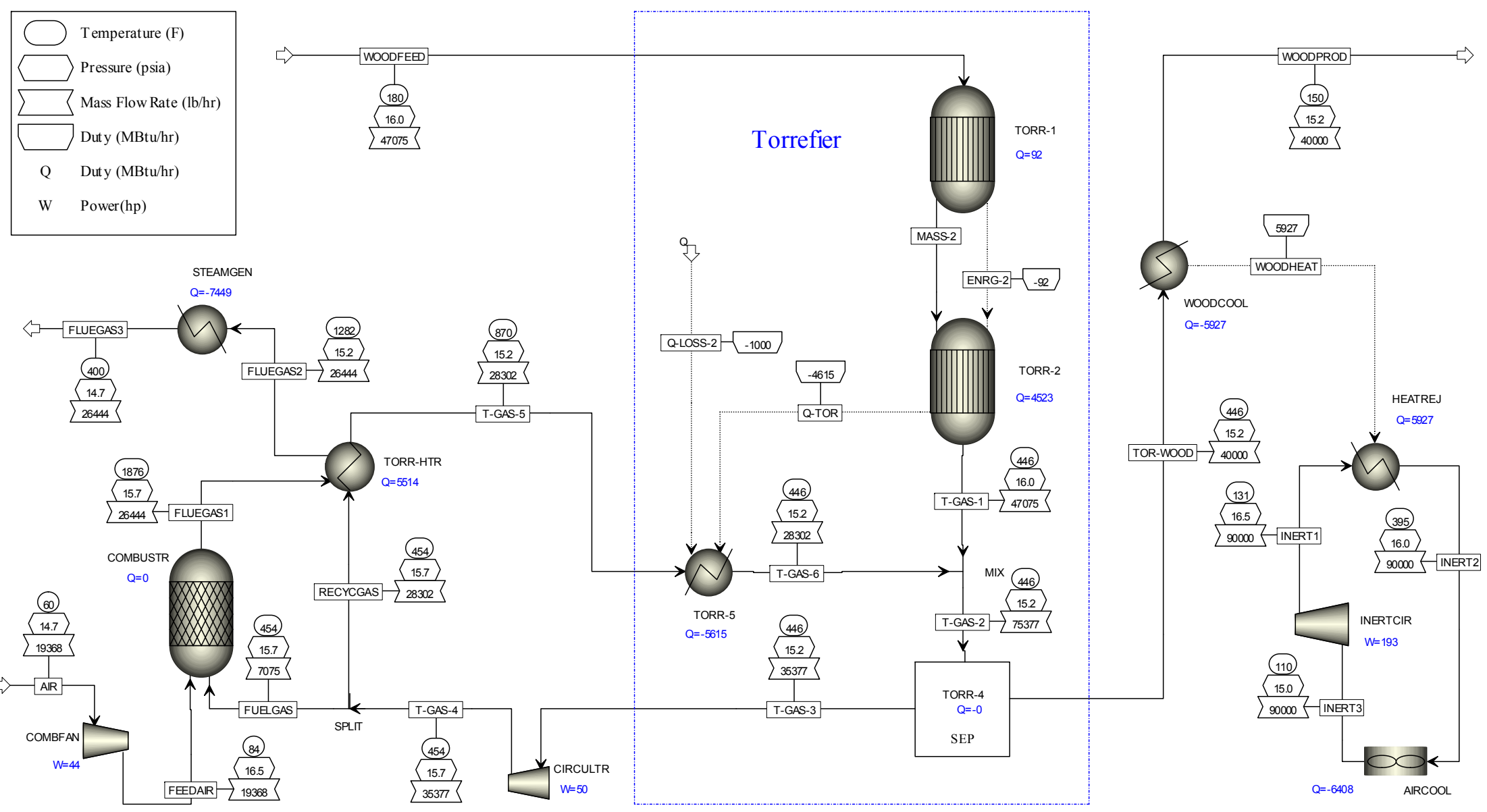




\section{Scenario 8. Depot-Biorefinery Thermal Integration 270 deg C}

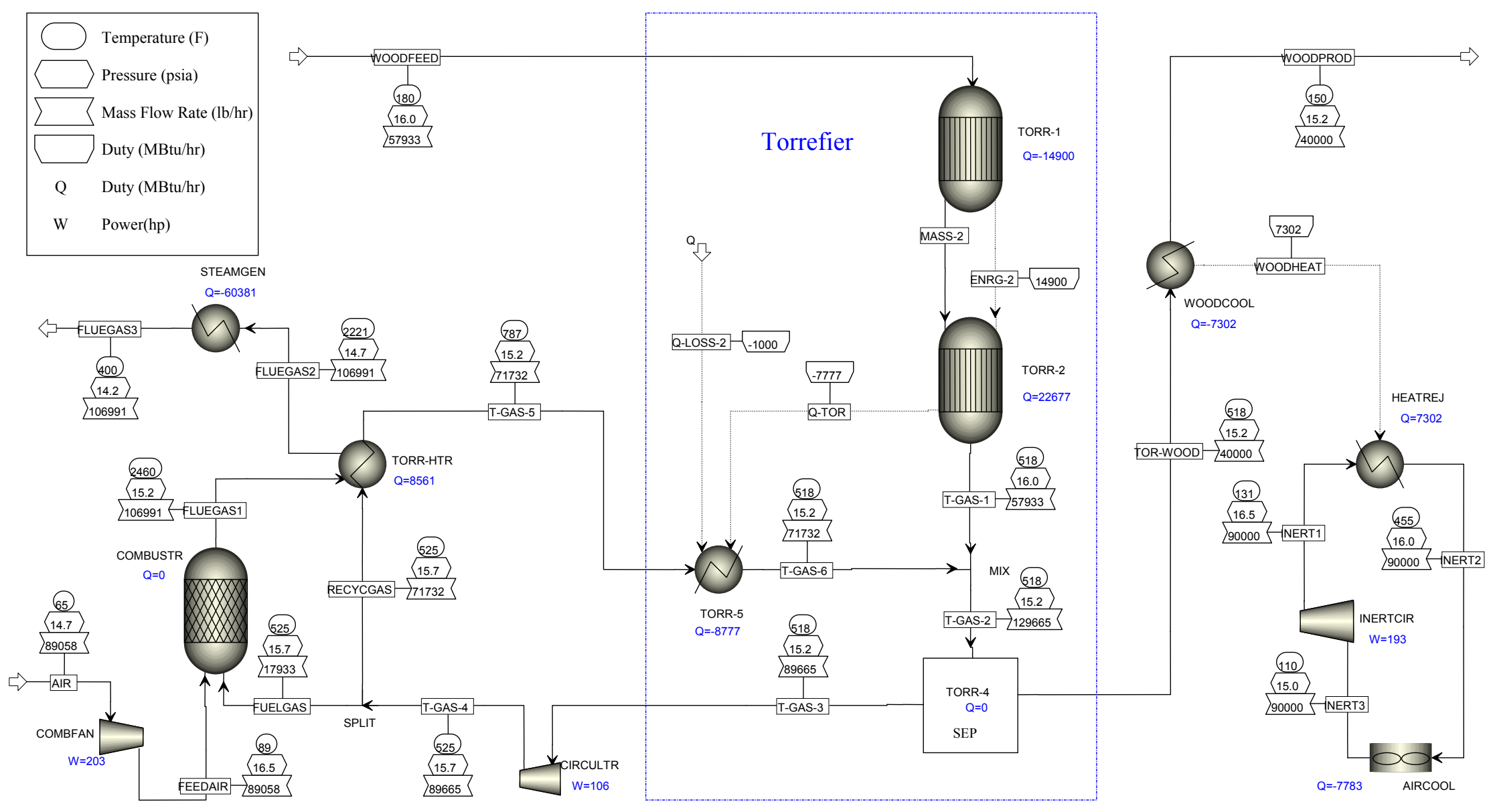




\section{Appendix 3 \\ Individual Equipment Item Cost Estimates}

Refinery Cases
$\mathbf{1 5 0}^{\circ} \mathbf{C}$ Deep Drying
Dryer
Feed Hopper / Rotary Valve
Product Bin / Cyclone
Dryer Gas Filter
Dryer Gas Blower
Regenerative Thermal Oxidizer
Stack
Air Blower
Conveyor belts

\section{$180^{\circ} \mathrm{C}$ Torrefaction}

\section{Dryer}

Torrefier

Feed Hopper / Rotary Valve

Surge Bin / Cyclone

Product Bin

Torrefaction Gas Blower

Dryer Gas Filter

Dryer Gas Blower

Torrefaction Gas Filter

Regenerative Thermal Oxidizer

Stack

Air Blower

Conveyor belts
Capacity / Performance Requirement

$125.0 \mathrm{ton} / \mathrm{hr} ; 25.0$ ton $/ \mathrm{hr}$ evaporation

$$
125.0 \mathrm{ton} / \mathrm{hr}
$$

$100.0 \mathrm{ton} / \mathrm{hr} ; 247,600 \mathrm{ft} 3 / \mathrm{min}$

$247,600 \mathrm{ft} 3 / \mathrm{min}$

$247,600 \mathrm{ft} 3 / \mathrm{min}$

$388,000 \mathrm{ft} 3 / \mathrm{min}$ (inlet)

$303,900 \mathrm{ft} 3 / \mathrm{min}$

$6,100 \mathrm{ft} 3 / \mathrm{min}$

$500 \mathrm{ft}$ troughed belt

$139.7 \mathrm{ton} / \mathrm{hr} ; 27.9$ ton $/ \mathrm{hr}$ evaporation

$111.7 \mathrm{ton} / \mathrm{hr} ; 23.2 \mathrm{MMBtu} / \mathrm{hr}$ duty $139.7 \mathrm{ton} / \mathrm{hr}$

$111.7 \mathrm{ton} / \mathrm{hr} ; 197,200 \mathrm{ft} 3 / \mathrm{min}$

100 ton $(1 \mathrm{hr})$

$172,500 \mathrm{ft} 3 / \mathrm{min}$

$197,200 \mathrm{ft} 3 / \mathrm{min}$

$197,200 \mathrm{ft} 3 / \mathrm{min}$

$172,500 \mathrm{ft} 3 / \mathrm{min}$

$483,000 \mathrm{ft} 3 / \mathrm{min}$ (inlet)

$453,100 \mathrm{ft} 3 / \mathrm{min}$

$8,300 \mathrm{ft} 3 / \mathrm{min}$

$500 \mathrm{ft}$ troughed belt

Total Unit Cost (\$)

\section{$\mathbf{2 3 0}^{\circ} \mathrm{C}$ Torrefaction w/ Hot Gas}

Dryer

Torrefier

Feed Hopper / Rotary Valve

Surge Bin / Cyclone

Product Bin

Torrefaction Gas Blower

Dryer Gas Filter

Dryer Gas Blower

Torrefaction Gas Filter

Regenerative Thermal Oxidizer

Stack

Air Blower

Conveyor belts

\author{
$147.1 \mathrm{ton} / \mathrm{hr} ; 29.4 \mathrm{ton} / \mathrm{hr}$ evaporation \\ 117.7 ton/hr; $17.9 \mathrm{MMBtu} / \mathrm{hr}$ duty \\ $147.1 \mathrm{ton} / \mathrm{hr}$ \\ $117.7 \mathrm{ton} / \mathrm{hr} ; 207,600 \mathrm{ft} 3 / \mathrm{min}$ \\ 100 ton $(1 \mathrm{hr})$ \\ $283,100 \mathrm{ft} 3 / \mathrm{min}$ \\ $207,600 \mathrm{ft} 3 / \mathrm{min}$ \\ $207,600 \mathrm{ft} 3 / \mathrm{min}$ \\ $283,100 \mathrm{ft} 3 / \mathrm{min}$ \\ $650,000 \mathrm{ft} 3 / \mathrm{min}$ \\ $610,800 \mathrm{ft} 3 / \mathrm{min}$ \\ $5,200 \mathrm{ft} 3 / \mathrm{min}$ \\ $500 \mathrm{ft}$ troughed belt
}

12,636,000

$2,289,000$

671,000

671,000

863,000

256,000

$7,218,000$

510,000

7,000

151,000

$\mathbf{1 7 , 8 6 9 , 0 0 0}$

$2,656,000$

$2,498,000$

671,000

671,000

671,000

184,000

692,000

168,000

618,000

$8,232,000$

648,000

9,000

151,000

23,663,000

$2,723,000$

$2,578,000$

671,000

671,000

671,000

304,000

723,000

216,000

969,000

$13,057,000$

923,000

6,000

151,000 
Dryer

Torrefier

Feed Hopper / Rotary Valve

Surge Bin / Cyclone

Product Bin

Torrefaction Gas Blower

Dryer Gas Filter

Dryer Gas Blower

Torrefaction Gas Filter

Fired Heater

Exchanger

Air Preheater

Air Blower

Stack

Conveyor belts
$147.1 \mathrm{ton} / \mathrm{hr} ; 29.4$ ton/hr evaporation

117.7 ton/hr; $17.9 \mathrm{MMBtu} / \mathrm{hr}$ duty $147.1 \mathrm{ton} / \mathrm{hr}$

$117.7 \mathrm{ton} / \mathrm{hr} ; 207,600 \mathrm{ft} 3 / \mathrm{min}$ 100 ton $(1 \mathrm{hr})$

$120,200 \mathrm{ft} 3 / \mathrm{min}$ $207,600 \mathrm{ft} 3 / \mathrm{min}$ $207,600 \mathrm{ft} 3 / \mathrm{min}$ $120,200 \mathrm{ft} 3 / \mathrm{min}$ 166.5 MMBtu/hr 23.0 MMBtu/hr

24,100 ft3/min; 11.9 MMBtu/hr $20,600 \mathrm{ft} 3 / \mathrm{min}$ $392,400 \mathrm{ft} 3 / \mathrm{min}$ $500 \mathrm{ft}$ troughed belt
$2,723,000$

$2,578,000$

671,000

671,000

671,000

141,000

723,000

216,000

460,000

$2,547,000$

159,000

125,000

20,000

594,000

151,000

\section{Depot Cases}

\section{$180^{\circ} \mathrm{C}$ Torrefaction}

Stoker Furnace

$$
\text { Exchanger }
$$

Dryer

Torrefier

Feed Hopper / Rotary Valve

Fuel Hopper / Rotary Valve

Surge Bin / Cyclone

Product Bin

Regenerative Thermal Oxidizer

Air Preheater

Stack

Air Blower

Torrefaction Gas Blower

Dryer Gas Filter

Torrefaction Gas Filter

Conveyor belts

\section{$230^{\circ} \mathrm{C}$ Torrefaction}

Stoker Furnace

$$
\text { Exchanger }
$$

Dryer

Torrefier

Feed Hopper / Rotary Valve

Fuel Hopper / Rotary Valve

Surge Bin / Cyclone

Product Bin

Regenerative Thermal Oxidizer

Air Preheater

Stack

Air Blower

Torrefaction Gas Blower

Dryer Gas Filter

Torrefaction Gas Filter

Conveyor belts
$2.41 \mathrm{ton} / \mathrm{hr} ; 29.36 \mathrm{MMBtu} / \mathrm{hr}$ 5.64 MMBtu/hr

27.9 ton $/ \mathrm{hr} ; 5.59$ ton $/ \mathrm{hr}$ evaproation $22.3 \mathrm{ton} / \mathrm{hr} ; 4.64 \mathrm{MMBtu} / \mathrm{hr}$ duty

$$
27.9 \mathrm{ton} / \mathrm{hr}
$$$$
2.8 \mathrm{ton} / \mathrm{hr}
$$

$22.3 \mathrm{ton} / \mathrm{hr} ; 27,100 \mathrm{ft} 3 / \mathrm{min}$

20 ton $(1 \mathrm{hr})$

29,300 ft3/min (inlet)

$15,200 \mathrm{ft} 3 / \mathrm{min}$ (inlet)

$29,200 \mathrm{ft} 3 / \mathrm{min}$

$15,200 \mathrm{ft} 3 / \mathrm{min}$

$32,400 \mathrm{ft} 3 / \mathrm{min}$

$27,100 \mathrm{ft} 3 / \mathrm{min}$

$32,400 \mathrm{ft} 3 / \mathrm{min}$

$300 \mathrm{ft}$ troughed belt
4,910,000

$1,417,000$

8,000

572,000

953,000

126,000

41,000

126,000

126,000

795,000

153,000

175,000

11,000

35,000

124,000

140,000

108,000

$4,841,000$

$1,320,000$

$2.01 \mathrm{ton} / \mathrm{hr} ; 24.56 \mathrm{MMBtu} / \mathrm{hr}$

8,000

4.57 MMBtu/hr

598,000

984,000

126,000

41,000

126,000

126,000

814,000

94,000

219,000

11,000

28,000

124,000

114,000

108,000 
$270^{\circ} \mathrm{C}$ Torrefaction

\section{Dryer}

Torrefier

Feed Hopper / Rotary Valve

Surge Bin / Cyclone

Product Bin

Fired Heater

Boiler

Stack

Exchanger

Air Blower

Torrefaction Gas Blower

Dryer Gas Blower

Dryer Gas Filter

Torrefaction Gas Filter

Conveyor belts



$1,113,000$

126,000

126,000

126,000

$1,349,000$

631,000

9,000

204,000

11,000

44,000

33,000

132,000

163,000

108,000

$\mathbf{5 , 0 5 4 , 0 0 0}$

29.0 ton/hr; $7.8 \mathrm{MMBtu} / \mathrm{hr}$ duty

$1,266,000$

30 ton

126,000

30 ton $(1 \mathrm{hr})$

$69 \mathrm{MMBtu} / \mathrm{hr} ; 125,000 \mathrm{ft} 3 / \mathrm{min}$ (outlet)

604MMBtu/hr

86MMBtu/hr

$39,000 \mathrm{ft} 3 / \mathrm{min}$

$19,700 \mathrm{ft} 3 / \mathrm{min}$

$34,200 \mathrm{ft} 3 / \mathrm{min}$

$34,200 \mathrm{ft} 3 / \mathrm{min}$

$21,800 \mathrm{ft} 3 / \mathrm{min}$

$21,800 \mathrm{ft} 3 / \mathrm{min}$

$300 \mathrm{ft}$ troughed belt

7.8 MMBTU/hr
126,000

$1,603,000$

$1,088,000$

8,000

208,000

13,000

37,000

227,000

14,000

117,000

108,000

113,000

Air cooler for inert gas

$230^{\circ} \mathrm{C}$ Depot at biorefinery using dried wood chips Torrefier

Feed Hopper / Rotary Valve

Product Bins

Fired Heater

Stack

Boiler

Exchanger

Air Blower for furnace

Torrefaction Gas Blower

Torrefaction Gas Filter

Cooler Gas Blower

Cooler Gas Filter

Conveyor belts

Air cooler for inert gas
$23.50 \mathrm{ton} / \mathrm{hr} ; 4.6 \mathrm{MMBtu} / \mathrm{hr}$ duty

$\mathbf{2 , 4 2 4 , 0 0 0}$ 30 ton

30 ton $(1 \mathrm{hr})$

922,000

126,000

126,000

377,000

309,000

7.4MMBtu/hr

5.5MMBtu/hr

$10,600 \mathrm{ft} 3 / \mathrm{min}$

$4250 \mathrm{ft} 3 / \mathrm{min}$

$16,900 \mathrm{ft} 3 / \mathrm{min}$

$16,900 \mathrm{ft} 3 / \mathrm{min}$

$21,800 \mathrm{ft} 3 / \mathrm{min}$

$21,800 \mathrm{ft} 3 / \mathrm{min}$

$300 \mathrm{ft}$ troughed belt

6.4 MMBTU/hr
5,000

95,000

11,000

20,000

90,000

14,000

117,000

108,000

104,000 


\section{Appendix 4 Derivation of Equipment Cost Estimates}

Equipment Type

Air cooler for inert gas

Air cooler for inert gas

Air Blower

Air Blower

Air Blower

Air Blower

Air Blower

Air Blower

Air Blower

Dryer Gas Blower

Dryer Gas Blower

Dryer Gas Blower

Dryer Gas Blower

Dryer Gas Blower

Torrefaction Gas Blowe

Torrefaction Gas Blowe

Torrefaction Gas Blowe

Torrefaction Gas Blowe

Torrefaction Gas Blowe

Torrefaction Gas Blower Air Blower
Capacity/Sizing Basis

Averag

installed

cost

7.8 MMBTU/hr

6.4 MMBTU/hr

113,000

104,000

$15,200 \mathrm{ft} 3 / \mathrm{min}$

$15,700 \mathrm{ft} 3 / \mathrm{min}$

$14,900 \mathrm{ft} 3 / \mathrm{min}$

$6,100 \mathrm{ft} 3 / \mathrm{min}$

$8,300 \mathrm{ft} 3 / \mathrm{min}$

$5,200 \mathrm{ft} 3 / \mathrm{min}$

$20,600 \mathrm{ft} 3 / \mathrm{min}$

$29,600 \mathrm{ft} 3 / \mathrm{min}$

$247,600 \mathrm{ft} 3 / \mathrm{min}$

$197,200 \mathrm{ft} 3 / \mathrm{min}$

$207,600 \mathrm{ft} 3 / \mathrm{min}$

$207,600 \mathrm{ft} 3 / \mathrm{min}$

$32,400 \mathrm{ft} 3 / \mathrm{min}$

$24,100 \mathrm{ft} 3 / \mathrm{min}$

$39,900 \mathrm{ft} 3 / \mathrm{min}$

$172,500 \mathrm{ft} 3 / \mathrm{min}$

$283,100 \mathrm{ft} 3 / \mathrm{min}$

$120,200 \mathrm{ft} 3 / \mathrm{min}$ $19,700 \mathrm{ft} 3 / \mathrm{min}$

\begin{tabular}{ccc}
\multicolumn{3}{c}{ Couper book } \\
\hline $\begin{array}{c}\text { Costing } \\
\text { basis }\end{array}$ units & $\begin{array}{c}\text { Couper } \\
\text { installed } \\
\text { cost } \\
\text { (2011) }\end{array}$ & Couper note \\
& & amb=75F, LMTD \\
& & $=158 F, U=10, A=4900$ \\
& & $f t 2$
\end{tabular}

\begin{tabular}{lccl}
\multicolumn{4}{c}{ Peters \& Timmerhaus } \\
\hline $\begin{array}{c}\text { Costin } \\
\text { g basis }\end{array}$ & units & $\begin{array}{c}\text { P\&T } \\
\text { installed } \\
\text { cost } \\
\mathbf{( 2 0 1 1 )}\end{array}$ & P\&T note \\
& & & \\
459 & $\mathrm{~m} 2$ & 112949 & $\begin{array}{l}\text { aluminum (not CS for } \\
\text { rust) }\end{array}$ \\
377 & $\mathrm{~m} 2$ & 103957 &
\end{tabular}

INL estimate / vendor quotes

Quote or Install

scaled cost in

estimate 2011
$A=4900 *(6.4 / 7.8)$

\begin{abstract}
carbon steel
\end{abstract}
carbon steel

carbon steel

carbon steel

carbon steel

carbon steel

carbon steel

stainless

stainless

stainless

stainless

stainless

stainless

stainless

stainless

stainless

stainless

stainless

7.17

7.41

$\mathrm{m} 3 / \mathrm{sec}$

11568

Heavy duty blower

3 in static pressure

$7.03 \mathrm{~m} 3 / \mathrm{sec} \quad 11394$

$2.88 \mathrm{~m} 3 / \mathrm{sec} \quad 6367$

$3.92 \mathrm{~m} 3 / \mathrm{sec} \quad 7636$

$2.45 \mathrm{~m} 3 / \mathrm{sec} \quad 5835$

$9.72 \mathrm{~m} 3 / \mathrm{sec} \quad 15110$

13.97

116.87

$\mathrm{m} 3 / \mathrm{sec}$

24703

306173

$93.08 \mathrm{~m} 3 / \mathrm{sec} \quad 262434$

$97.99 \mathrm{~m} 3 / \mathrm{sec} \quad 262434$

$97.99 \mathrm{~m} 3 / \mathrm{sec}$

262434

$15.29 \mathrm{~m} 3 / \mathrm{sec}$

29489

$11.38 \mathrm{~m} 3 / \mathrm{sec} \quad 18076$

$$
18.83
$$

$$
81.4
$$$$
133.62
$$

56.73

$\begin{array}{r}9.30 \\ \hline\end{array}$

$78.5 \mathrm{~m} 3 / \mathrm{s} \mathrm{max}$
$7 \times 18 \mathrm{~m} 3 / \mathrm{s}$
6 ea
6 ea
6 ea
1 ea
5 ea
8 ea
4 ea
heavy duty 3 psi

\begin{tabular}{cc}
11867 & 12304 \\
12100 & 12546 \\
& \\
11726 & 12158 \\
& \\
9550 & 9902 \\
& \\
11900 & 12338 \\
& \\
8678 & 8997 \\
& \\
32300 & 33489 \\
& \\
39000 & 40436 \\
& 20736 \\
200000 & 4 \\
& \\
41384 & 42908 \\
& 17574 \\
169500 & 1 \\
& 17574 \\
169500 & 1 \\
& \\
36626 & 37975 \\
& \\
35489 & 36796 \\
& \\
41500 & 43028 \\
& 16174 \\
156000 & 4 \\
& 26335 \\
254000 & 2 \\
& 13022 \\
125601 & 6 \\
13865 & 14376 \\
\hline & \\
& \\
& \\
& \\
& \\
& \\
&
\end{tabular}




\begin{tabular}{|c|c|c|c|c|c|c|c|c|c|c|c|c|}
\hline Cooler Gas Blower & $21,800 \mathrm{ft} 3 / \mathrm{min}$ & 13,000 & 21.8 & KSCFM & 10777 & carbon steel & 10.29 & $\mathrm{~m} 3 / \mathrm{sec}$ & 16048 & $\begin{array}{c}\text { blower } \\
\text { heavy duty } 3 \text { psi } \\
\text { blower }\end{array}$ & 14734 & 15276 \\
\hline Torrefaction Gas Blower & $34,200 \mathrm{ft} 3 / \mathrm{min}$ & 37,000 & 34.2 & KSCFM & 37997 & stainless & 16.14 & $\mathrm{~m} 3 / \mathrm{sec}$ & 33242 & $\begin{array}{l}\text { heavy duty } 3 \text { psi } \\
\text { blower }\end{array}$ & 37834 & 39227 \\
\hline Air Blower for furnace & $4250 \mathrm{ft} 3 / \mathrm{min}$ & 11,000 & 4.3 & KSCFM & 4091 & carbon steel & 2.01 & $\mathrm{~m} 3 / \mathrm{sec}$ & 5289 & & 21993 & 22803 \\
\hline Torrefaction Gas Blower & $16,900 \mathrm{ft} 3 / \mathrm{min}$ & 20,000 & 16.9 & KSCFM & 22512 & stainless & 7.98 & $\mathrm{~m} 3 / \mathrm{sec}$ & 12611 & & 24785 & 25698 \\
\hline & $\begin{array}{c}15,200 \mathrm{ft} 3 / \mathrm{min} \\
\text { (inlet); } 3.41\end{array}$ & & & & & Use air cooler & & & & & & \\
\hline Air Preheater & $\begin{array}{c}\text { MMBTU/hr } \\
15,700 \mathrm{ft} 3 / \mathrm{min} \\
\text { (inlet); } 7.29\end{array}$ & 153,000 & 7160.3 & $\mathrm{sq} \mathrm{ft}$ & 96132 & formujla & 665 & $\mathrm{~m} 2$ & 264118 & SS air cooler eqn & 95039 & 98539 \\
\hline Air Preheater & MMBTU/hr & 94,000 & 7130.4 & $\mathrm{sq} \mathrm{ft}$ & 95971 & & 662 & $\mathrm{~m} 2$ & 87871 & CS air cooler eqn & 94800 & 98291 \\
\hline Dryer & $\begin{array}{l}27.9 \text { ton } / \mathrm{hr} ; 5.59 \\
\text { ton/hr evaporation }\end{array}$ & 572,000 & 1120.0 & $\begin{array}{l}\mathrm{sq} f t \\
\text { wall } \\
\text { area } \\
\text { sq ft }\end{array}$ & 609161 & $\begin{array}{l}10 \mathrm{lb} / \mathrm{hr} / \mathrm{ft} 2 \text { evap } \\
\text { from Table } 9.2\end{array}$ & 104 & $\begin{array}{l}\mathrm{m} 2 \text { wall } \\
\text { area }\end{array}$ & 535573 & $92.9 \mathrm{~m} 2 \mathrm{max}$ & & \\
\hline Dryer & $\begin{array}{c}29.4 \text { ton } / \mathrm{hr} ; 5.88 \\
\text { ton/hr evaporation }\end{array}$ & 598,000 & 1180.0 & $\begin{array}{l}\text { wall } \\
\text { area } \\
\text { sq ft }\end{array}$ & 632518 & Use direct contact & 110 & $\begin{array}{l}\mathrm{m} 2 \text { wall } \\
\text { area }\end{array}$ & 564264 & & & \\
\hline Dryer & $\begin{array}{c}36.2 \mathrm{ton} / \mathrm{hr} ; 7.24 \\
\text { ton/hr evaporation }\end{array}$ & 715,000 & 1450.0 & $\begin{array}{l}\text { wall } \\
\text { area } \\
\text { sq ft }\end{array}$ & 737450 & w/ combust. gas & 135 & $\begin{array}{l}\mathrm{m} 2 \text { wall } \\
\text { area }\end{array}$ & 693376 & & & \\
\hline Dryer & $\begin{array}{l}125.0 \text { ton } / \mathrm{hr} ; 25.0 \\
\text { ton/hr evaporation }\end{array}$ & $2,289,000$ & 5000.0 & $\begin{array}{l}\text { wall } \\
\text { area } \\
\text { sq ft }\end{array}$ & 2187781 & & 465 & $\begin{array}{l}\mathrm{m} 2 \text { wall } \\
\text { area }\end{array}$ & 2390950 & 5 ea & & \\
\hline Dryer & $\begin{array}{l}139.7 \text { ton/hr; } 27.9 \\
\text { ton/hr evaporation }\end{array}$ & $2,656,000$ & 5580.0 & $\begin{array}{l}\text { wall } \\
\text { area } \\
\text { sq ft }\end{array}$ & 2442403 & & 518 & $\begin{array}{l}\mathrm{m} 2 \text { wall } \\
\text { area }\end{array}$ & 2869140 & 6 ea & & \\
\hline Dryer & $\begin{array}{l}147.1 \mathrm{ton} / \mathrm{hr} ; 29.4 \\
\text { ton/hr evaporation }\end{array}$ & $2,723,000$ & 5880.0 & $\begin{array}{l}\text { wall } \\
\text { area } \\
\text { sq ft }\end{array}$ & 2576159 & & 546 & $\begin{array}{l}\mathrm{m} 2 \text { wall } \\
\text { area }\end{array}$ & 2869140 & 6 ea & & \\
\hline Dryer & $\begin{array}{l}147.1 \text { ton/hr; } 29.4 \\
\text { ton/hr evaporation }\end{array}$ & $2,723,000$ & 5880.0 & $\begin{array}{l}\text { wall } \\
\text { area }\end{array}$ & 2576159 & & 546 & $\begin{array}{l}\mathrm{m} 2 \text { wall } \\
\text { area }\end{array}$ & 2869140 & 6 ea & & \\
\hline Dryer Gas Filter & $27,100 \mathrm{ft} 3 / \mathrm{min}$ & 124,000 & & & & & 12.8 & $\mathrm{~m} 3 / \mathrm{s}$ & 159663 & fabric filter & 84384 & 87491 \\
\hline Dryer Gas Filter & $27,700 \mathrm{ft} 3 / \mathrm{min}$ & 124,000 & & & & & 12.8 & $\mathrm{~m} 3 / \mathrm{s}$ & 159663 & dust collector & 85500 & 88648 \\
\hline Dryer Gas Filter & $29,600 \mathrm{ft} 3 / \mathrm{min}$ & 132,000 & & & & & 14.0 & $\mathrm{~m} 3 / \mathrm{s}$ & 170913 & $230 \mathrm{C}$, continuous & 88972 & $\begin{array}{l}92248 \\
60031\end{array}$ \\
\hline Dryer Gas Filter & $247,600 \mathrm{ft} 3 / \mathrm{min}$ & 863,000 & & & & & 117.0 & $\mathrm{~m} 3 / \mathrm{s}$ & 1126333 & stainless steel & 579000 & $\begin{array}{c}9 \\
48708\end{array}$ \\
\hline Dryer Gas Filter & $197,200 \mathrm{ft} 3 / \mathrm{min}$ & 692,000 & & & & & 93.1 & $\mathrm{~m} 3 / \mathrm{s}$ & 896671 & $470 \mathrm{~m} 3 / \mathrm{s} \max$ & 469788 & $\begin{array}{c}5 \\
50234\end{array}$ \\
\hline Dryer Gas Filter & $207,600 \mathrm{ft} 3 / \mathrm{min}$ & 723,000 & & & & & 98.0 & $\mathrm{~m} 3 / \mathrm{s}$ & 943269 & & 484500 & $\begin{array}{c}0 \\
50234\end{array}$ \\
\hline Dryer Gas Filter & $207,600 \mathrm{ft} 3 / \mathrm{min}$ & 723,000 & & & & & 98.0 & $\mathrm{~m} 3 / \mathrm{s}$ & 943269 & & 484500 & 0 \\
\hline Torrefaction Gas Filter & $32,400 \mathrm{ft} 3 / \mathrm{min}$ & & & & & & 15.3 & $\mathrm{~m} 3 / \mathrm{s}$ & 183011 & & 93930 & 97389 \\
\hline
\end{tabular}




\begin{tabular}{|c|c|c|c|c|c|c|c|c|c|c|c|c|c|}
\hline & & 140,000 & & & & & & & & & & & \\
\hline Torrefaction Gas Filter & $24,100 \mathrm{ft} 3 / \mathrm{min}$ & 114,000 & & & & & 11.4 & $\mathrm{~m} 3 / \mathrm{s}$ & 146414 & & 78648 & $\begin{array}{l}81544 \\
11034\end{array}$ & \\
\hline Torrefaction Gas Filter & $39,900 \mathrm{ft} 3 / \mathrm{min}$ & 163,000 & & & & & 18.8 & $\mathrm{~m} 3 / \mathrm{s}$ & 215234 & & 106429 & $\begin{array}{c}8 \\
44950\end{array}$ & \\
\hline Torrefaction Gas Filter & $172,500 \mathrm{ft} 3 / \mathrm{min}$ & 618,000 & & & & & 81.4 & $\mathrm{~m} 3 / \mathrm{s}$ & 786419 & & 433542 & $\begin{array}{c}5 \\
65057\end{array}$ & \\
\hline Torrefaction Gas Filter & $283,100 \mathrm{ft} 3 / \mathrm{min}$ & 969,000 & & & & & 133.5 & $\mathrm{~m} 3 / \mathrm{s}$ & 1286836 & & 627469 & $\begin{array}{c}3 \\
36191\end{array}$ & \\
\hline Torrefaction Gas Filter & $120,200 \mathrm{ft} 3 / \mathrm{min}$ & 460,000 & & & & & 56.7 & $\mathrm{~m} 3 / \mathrm{s}$ & 558152 & & 349060 & 3 & \\
\hline Torrefaction Gas Filter & $34,200 \mathrm{ft} 3 / \mathrm{min}$ & 227,000 & & & & & 16.1 & $\mathrm{~m} 3 / \mathrm{s}$ & 352789 & stainless steel & 97027 & $\begin{array}{c}10060 \\
0\end{array}$ & \\
\hline Torrefaction Gas Filter & $16,900 \mathrm{ft} 3 / \mathrm{min}$ & 90,000 & & & & & 8.0 & $\mathrm{~m} 3 / \mathrm{s}$ & 113431 & stainless steel & 63564 & 65904 & \\
\hline Cooler Gas Filter & $21,800 \mathrm{ft} 3 / \mathrm{min}$ & 117,000 & & & & & 10.3 & $\mathrm{~m} 3 / \mathrm{s}$ & 156958 & & 74055 & 76781 & \\
\hline & & & & $\begin{array}{l}\text { vendor } \\
\text { quote }\end{array}$ & $\begin{array}{c}\text { NOT } \\
\text { COUPER }\end{array}$ & 2011 cost & & & & & & & \\
\hline Bin/Cyclone/Rotary Valve & $\begin{array}{c}\text { nominal } 3 \text { tons, } 1 \mathrm{hr} \\
\text { inventory } \\
\text { nominal } 30 \text { tons, } 1 \mathrm{hr}\end{array}$ & 41,000 & 21600.0 &  & 22395 & rotary valve (quote) & 1.4 & $\mathrm{~m} 3 / \mathrm{s}$ & 4714 & $\begin{array}{l}\text { CS single cyclone } \\
\text { (P\&T) } \\
\text { SS cyclones only }\end{array}$ & 13439 & 13933 & $\begin{array}{l}\text { SS bin } \\
\text { only } \\
\text { SS bin }\end{array}$ \\
\hline Bin/Cyclone/Rotary Valve & $\begin{array}{c}\text { inventory } \\
\text { nominal } 120 \text { tons, } 1\end{array}$ & 126,000 & 21600.0 & & 22395 & rotary valve (quote) & 14 & $\mathrm{~m} 3 / \mathrm{s}$ & 48047 & $\begin{array}{c}\text { (P\&T) } \\
\text { SS cyclones only }\end{array}$ & 53500 & $\begin{array}{l}55470 \\
25464\end{array}$ & $\begin{array}{l}\text { only } \\
\text { SS bin }\end{array}$ \\
\hline Bin/Cyclone/Rotary Valve & hr inventory & 671,000 & 48500.0 & & 50286 & rotary valve (quote) & 99 & $\mathrm{~m} 3 / \mathrm{s}$ & 366000 & (P\&T) & 245600 & 3 & only \\
\hline Feed Hopper / Rotary Valve & 27.9 ton $/ \mathrm{hr}$ & 22,000 & & & & & & & & & 20932 & 21703 & \\
\hline Feed Hopper / Rotary Valve & $29.4 \mathrm{ton} / \mathrm{hr}$ & 22,000 & & & & & & & & & 21600 & 22395 & \\
\hline Feed Hopper / Rotary Valve & 36.2 ton $/ \mathrm{hr}$ & 25,000 & & & & & & & & & 24513 & 25415 & \\
\hline Feed Hopper / Rotary Valve & $125.0 \mathrm{ton} / \mathrm{hr}$ & 50,000 & & & & & & & & & 48500 & 50286 & \\
\hline Feed Hopper / Rotary Valve & $139.7 \mathrm{ton} / \mathrm{hr}$ & 54,000 & & & & & & & & & 51846 & 53755 & \\
\hline Feed Hopper / Rotary Valve & $147.1 \mathrm{ton} / \mathrm{hr}$ & 98,000 & & & & & & & & & 94900 & 98394 & \\
\hline Feed Hopper / Rotary Valve & $147.1 \mathrm{ton} / \mathrm{hr}$ & 98,000 & & & & & & & & & 94900 & 98394 & \\
\hline Fuel Hopper / Rotary Valve & $2.8 \mathrm{ton} / \mathrm{hr}$ & 22,000 & & & & & & & & & 21600 & 22395 & \\
\hline Fuel Hopper / Rotary Valve & $2.1 \mathrm{ton} / \mathrm{hr}$ & 19,000 & & & & & & & & & 18176 & 18845 & \\
\hline Product Bin & 20 ton $(1 \mathrm{hr})$ & 55,000 & & & & & & & & & 53500 & 55470 & \\
\hline Product Bin & 20 ton $(1 \mathrm{hr})$ & 55,000 & & & & & & & & & 53500 & 55470 & \\
\hline Product Bin & 20 ton $(1 \mathrm{hr})$ & 55,000 & & & & & & & & & 53500 & $\begin{array}{l}55470 \\
25464\end{array}$ & \\
\hline Product Bin & 100 ton $(1 \mathrm{hr})$ & 255,000 & & & & & & & & & 245600 & $\begin{array}{c}3 \\
25464\end{array}$ & \\
\hline Product Bin & 100 ton $(1 \mathrm{hr})$ & 255,000 & & & & & & & & & 245600 & 3 & \\
\hline
\end{tabular}






\begin{tabular}{|c|c|c|}
\hline & 25464 & \\
\hline 245600 & 3 & \\
\hline 75283 & 78055 & \\
\hline 18299 & 18973 & \\
\hline 18884 & 19579 & \\
\hline 21423 & 22212 & \\
\hline 80451 & 83413 & \\
\hline 80451 & 83413 & \\
\hline 80451 & 83413 & \\
\hline 808000 & $\begin{array}{c}83775 \\
1 \\
60900 \\
0\end{array}$ & 631424 \\
\hline 1595000 & $\begin{array}{c}16537 \\
29\end{array}$ & \\
\hline & $\begin{array}{c}12080 \\
0\end{array}$ & 125248 \\
\hline & $\begin{array}{c}10488 \\
84\end{array}$ & $\begin{array}{c}108750 \\
5\end{array}$ \\
\hline & 29760 & \\
\hline & 8 & 308566 \\
\hline
\end{tabular}

process furnace

CS tubes, 500 psia

process furnace

CS tubes, 500 psia

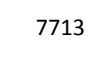

3800

kW

377228$$
\text { . }
$$

$\begin{array}{cc} & 79453 \\ 766320 & 7 \\ & 81390 \\ 785000 & 4 \\ & 72183 \\ 6962000 & 46 \\ & 82320 \\ 7939685 & 29 \\ 12593000 & 13056\end{array}$


Stack

$29,200 \mathrm{ft} 3 / \mathrm{min}$

$42,300 \mathrm{ft} 3 / \mathrm{min}$

$37,500 \mathrm{ft} 3 / \mathrm{min}$

$303,900 \mathrm{ft} 3 / \mathrm{min}$

$453,100 \mathrm{ft} 3 / \mathrm{min}$

$610,800 \mathrm{ft} 3 / \mathrm{min}$

$392,400 \mathrm{ft} 3 / \mathrm{min}$

$39,000 \mathrm{ft} 3 / \mathrm{min}$

$10,600 \mathrm{ft} 3 / \mathrm{min}$

$2.41 \mathrm{ton} / \mathrm{hr} ; 29.36$ $\mathrm{MMBtu} / \mathrm{hr}$

Stoker Furnace

Stoker Furnace

Torrefier

Torrefier

Torrefier

Torrefier

Torrefier

Torrefier

Torrefier

Torrefier

Conveyors

Conveyors
Exchanger

$2.01 \mathrm{ton} / \mathrm{hr} ; 24.56$ MMBtu/hr

\section{Exchanger}

22.3 ton/hr; 4.64 MMBtu/hr duty

23.5 ton/hr; 3.57

MMBtu/hr duty

29.0 ton/hr; 6.29

MMBtu/hr duty

111.7 ton/hr; 23.2

MMBtu/hr duty

MMBtu/hr duty

MMBtu/hr duty

117.7 ton/hr; 17.9

$\mathrm{MMBtu} / \mathrm{hr}$ duty
$29.0 \mathrm{ton} / \mathrm{hr} ; 7.8$

29.0 ton/hr; 7.8

23.50 ton/hr; 4.6

MMBtu/hr duty

$300 \mathrm{ft}$ troughed belts for 20 tpd systems

$500 \mathrm{ft}$ troughed belts

for 100 tpd systems



U-tube

853.3

53.6

m2 wall (use same area as dryer specified for the same process)

104

110

135

518

546

546
$17522 \quad 40^{\prime}$ high

$\begin{array}{ccc}169000 & 17522 & 40^{\prime} \text { high } \\ & 3 & \times 8^{\prime} \text { dia } \\ & 21885 & \\ 211087 & 9 & \\ & 20360 & \\ 196370 & 1 & \\ & 50963 & \\ 491536 & 5 & \\ & 64764 & \\ 624646 & 5 & \\ & 92277 & 60^{\prime} \text { high } \\ 890000 & 0 & \times 20^{\prime} \text { dia } \\ & 59409 & 60^{\prime} \text { high } \\ 573000 & 8 & \times 16^{\prime} \text { dia } \\ & 20802 & \\ 200634 & 2 & \\ & & \\ 91823 & 95204 & \end{array}$

Unused surplus $262 \mathrm{~m} 2$ calciner is $\$ 400 \mathrm{~K}$ quote. Use $4 \mathrm{x}$ for new cost

$919347 \quad 953198$

9485889983516

$1073419 \quad 1112943$

$2409512 \quad 2498232$

$2486423 \quad 2577975$

$2486423 \quad 2577975$

$1221338 \quad 1266308$

$889680 \quad 922438$ 


\section{Appendix 5 Example Factored Estimate of Total Facility Cost}

\section{ESTIMATION OF CAPITAL INVESTMENT BY PERCENTAGE OF DELIVERED EQUIPMENT METHOD}

(See Table 6-9, Peters et al.)

The fractions in the cells below are approximations applicable to typical chemical processing

plants. These values may differ depending on many factors such as location, process type, etc.

\begin{tabular}{|c|c|c|c|c|c|}
\hline Required user input & Default & Subtotal & Result \\
\hline Required, from a linked sheet or entered manually & & $\begin{array}{c}\text { Notes \& } \\
\text { comments }\end{array}$ & \\
\hline & Fraction of delivered equipment & User: copy \\
Project Identifier: Depot 230 deg C & $\begin{array}{c}\text { Solid- } \\
\text { processing } \\
\text { plant }\end{array} \quad \begin{array}{c}\text { Solid-fluid } \\
\text { processing } \\
\text { plant }\end{array}$ & $\begin{array}{c}\text { Fluid } \\
\text { processing } \\
\text { plant }\end{array}$ & $\begin{array}{c}\text { values at left or } \\
\text { insert }\end{array}$ & $\begin{array}{c}\text { Calculated } \\
\text { values, } \\
\text { million \$ }\end{array}$ \\
\hline
\end{tabular}

Purchased equipment, $E^{\prime}$

Direct Costs

Delivery, fraction of $\mathrm{E}^{\prime}$

Subtotal: delivered equipment

Purchased equipment installation Instrumentation \& Controls(installed)

Piping (installed)

Electrical systems (installed)

Buildings (including services)

Yard improvements

Service facilities (installed)

Total direct costs

\begin{tabular}{|l|l|l|l|l|}
\hline 0.10 & 0.10 & 0.10 & 0.10 & 4.841 \\
\hline & & & & 0.484 \\
\hline 0.45 & 0.39 & 0.47 & 0.45 & 2.325 \\
\hline 0.18 & 0.26 & 0.36 & 0.18 & 0.959 \\
\hline 0.16 & 0.31 & 0.68 & 0.16 & 0.852 \\
\hline 0.10 & 0.10 & 0.11 & 0.10 & 0.533 \\
\hline 0.25 & 0.29 & 0.18 & 0.25 & 1.331 \\
\hline 0.15 & 0.12 & 0.10 & 0.15 & 0.799 \\
\hline 0.40 & 0.55 & 0.70 & 0.40 & 2.130 \\
\hline
\end{tabular}

Engineering and supervision

Construction expenses

Legal expenses

Contractor's fee

Contingency

Total indirect costs

Indirect Costs
\begin{tabular}{|c|c|c|c|c|}
\hline 0.33 & 0.32 & 0.33 & 0.33 & 1.757 \\
\hline 0.39 & 0.34 & 0.41 & 0.39 & 2.077 \\
\hline 0.04 & 0.04 & 0.04 & 0.04 & 0.213 \\
\hline 0.17 & 0.19 & 0.22 & 0.17 & 0.905 \\
\hline 0.35 & 0.37 & 0.44 & 0.35 & 1.864 \\
\hline 1.28 & 1.26 & 1.44 & 1.28 & 6.816 \\
\hline
\end{tabular}

Fixed capital investment (FCl)

21.141

Working capital (WC)

0.70

0.75

0.89

0.70

3.728

Total capital investment (TCI)

24.868 
